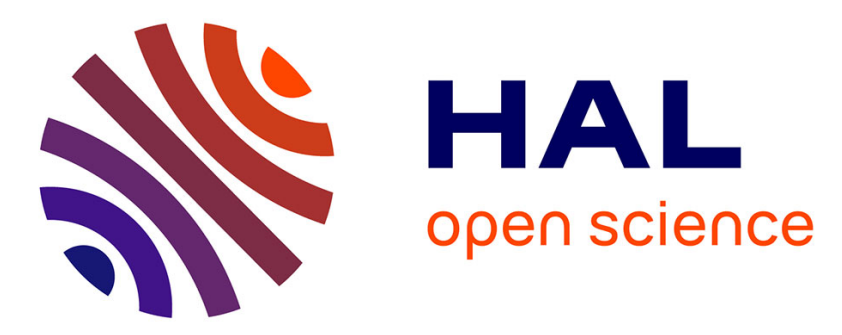

\title{
On the late Pleistocene-Holocene sapropel record of climatic and oceanographic variability in the eastern Mediterranean
}

\author{
S. Calvert, M. Fontugne
}

\section{- To cite this version:}

S. Calvert, M. Fontugne. On the late Pleistocene-Holocene sapropel record of climatic and oceanographic variability in the eastern Mediterranean. Paleoceanography, 2001, 16 (1), pp.78-94. 10.1029/1999PA000488 . hal-02501086

\section{HAL Id: hal-02501086 \\ https://hal.science/hal-02501086}

Submitted on 8 Feb 2021

HAL is a multi-disciplinary open access archive for the deposit and dissemination of scientific research documents, whether they are published or not. The documents may come from teaching and research institutions in France or abroad, or from public or private research centers.
L'archive ouverte pluridisciplinaire HAL, est destinée au dépôt et à la diffusion de documents scientifiques de niveau recherche, publiés ou non, émanant des établissements d'enseignement et de recherche français ou étrangers, des laboratoires publics ou privés. 


\title{
On the late Pleistocene-Holocene sapropel record of climatic and oceanographic variability in the eastern Mediterranean
}

\author{
S. E. Calvert \\ Earth and Ocean Sciences, University of British Columbia, Vancouver, Canada
}

\author{
M. R. Fontugne \\ Laboratoire des Sciences du Climat et de l'Environnement, Gif-sur-Yvette, France
}

\begin{abstract}
Sapropels and intercalated marls in a piston core from the eastern Mediterranean are chemically and mineralogical distinct: kaolinite, smectite, and total $\mathrm{S}$ contents, $\mathrm{Fe} / \mathrm{Al}, \mathrm{Ba} / \mathrm{Al}, \mathrm{Co} / \mathrm{Al}, \mathrm{Mo} / \mathrm{Al}$, and $\mathrm{V} / \mathrm{Al}$ are higher, whereas quartz, $\mathrm{Mg}$ calcite, illite contents, $\mathrm{Si} / \mathrm{Al}, \mathrm{Ti} / \mathrm{Al}, \mathrm{K} / \mathrm{Al}, \mathrm{Rb} / \mathrm{Al}$, and $\mathrm{Zr} / \mathrm{Al}$ are lower in the sapropels. Missing and "ghost" sapropels are identified by mineralogical and chemical properties that are not prone to diagenesis. Primary production was higher $(\mathrm{Ba} / \mathrm{Al})$ and bottom water and/or interstitial oxygenation was lower (Co/Al, $\mathrm{Mo} / \mathrm{Al}, \mathrm{Ni} / \mathrm{Al}$, and $\mathrm{V} / \mathrm{Al}$ ) during sapropel formation. Wind speeds (quartz/clay, Si/Al, and $\mathrm{Zr} / \mathrm{Al}$ ) and bottom water salinities (Mg calcite/calcite) were higher during periods of marl formation. Sapropels represent a fundamentally different sedimentary facies whose formation is linked to changes in the hydrological balance in the basin, driven by precessionally modulated changes in monsoon strength and subtropical precipitation changes, which altered circulation, production, and sediment source areas.
\end{abstract}

\section{Introduction}

Sequences of organic-rich muds (sapropels) in the Holocene and late Neogene coccolith-foraminiferal marl oozes of the eastem Mediterranean have been a rich source of information on palaeoclimatic and palaeoceanographic variability [Olausson, 1961; Williams and Thunell, 1979; Rossignol-Strick, 1985; Rohling, 1994]. These distinctive deposits were formed during periods of increased freshwater influx into the eastern basin when insolation-driven strengthening of the monsoon led to increased rainfall in the northern and southern Mediterranean borderlands. These influxes caused profound changes in surface and deep circulation, productivity, bottom water oxygenation, and sediment supply. The tight link betwee!. the intervals of sapropel deposition and insolation maxima at the precessional frequency (albeit with a lag of a few thousand years) led, beginning with the seminal paper of Hilgen [1987], to the extensive use of sapropel sequences in the circum-Mediterranean region for erecting highresolution astronomical chronologies over the last $10 \mathrm{Myr}$ [Hilgen et al., 1995; Langereis et al., 1997]. The recovery of sapropels in the western Mediterranean during Ocean Drilling Program Leg 161 [Murat, 1999] demonstrates that unusual changes in climatic and/or oceanographic conditions have intermittently affected the entire Mediterranean over the last 3 million years.

In a prescient paper, Bradley [1938] predicted the occurrence of laminated, organic-rich sediments in the glacial age sediments of the eastern basin of the Mediterranean on the basis of the likely change in climate and/or lowered sea level at this time. By analogy with hydrographically restricted fjords and the Black Sea he reasoned that a wetter and cooler glacial climare, as generally

Copyright 2001 by the American Geophysical Union.

Paper number 1999PA000488.

0883-8305/01/1999PA000488 $\$ 12.00$ accepted at that time [Brooks, 1949], would have reversed the circulation of the eastern basin because of the presence of a lower-salinity surface layer and this would have led to deep water stagnation due to restricted deep water renewal. Kullenberg [1952] and Olausson [1961] extended this reasoning after the sapropels were first sampled during the Swedish Deep-Sea Expedition, and they suggested that the increased supply of fresh water from the Black Sea and from the pluvial condition of the Mediterranean region after the glacial maximum were instrumental in creating an anoxic basin which led to the formation of the sapropels. This explanation would be consistent with the occurrence of many sapropels during "warming trends" [Ryan, 1972]. It is now known that the sapropels formed mainly after, not during, the glacial maxima and are closely related to the precessional cycle of the monsoons [Rossignol-Strick et al., 1982].

The evidence for the formation of the sapropels via increased organic carbon preservation under bottom water anoxia has recently been reviewed by Emeis and Party [1996] and Cramp and O'Sullivan [1999], and this mechanism is now widely accepted. Basin stagnation is held to be caused by greatly increased runoff [Rossignol-Strick et al., 1982; Rossignol-Strick, 1983, 1985] or an altered hydrographic balance which decreased evaporative water losses [Rohling and Hilgen, 1991; Rohling, 1994]. An additional factor originally suggested by Berger [1976] is a higher settling flux of organic matter caused by increased primary production when the circulation and the nutrient budget of the eastern basin were altered by the changed hydrographic conditions [Calvert, 1983]. Rohling [1989] suggested that pycnocline shoaling induced the formation of a deep chlorophyll maximum at times of sapropel formation, and Sancetra [1994] proposed that large fluxes of mat-forming diatoms were responsible for high carbon fluxes, a suggestion that has recently been confirmed for one of the prominent late Pleistocene sapropel 
horizons [Kemp et al., 1999]. The current view appears to be converging on a combined mechanism, whereby high carbon fluxes cause oxygen drawdown in deep water, leading to enhanced organic preservation [Sancetta, 1999].

The palaeoclimatic and palaeoceanographic information stored in the sapropel records, whatever mechanism is principally involved in their formation, includes the sources of organic matter [ten Haven et al., 1987a, 1987b, 1987c], changes in freshwater balance [Thunell and Williams, 1989; Rohling and Hilgen, 1991; Rohling and De Rijk, 1999], glacial-interglacial changes in atmospheric $p \mathrm{CO}_{2}$ [Fontugne and Calvert, 1992], and relative nutrient utilization [Calvert et al., 1992]. The goals of this study were to acquire further insight into environmental changes over several glacial-interglacial cycles in the eastern Mediterranean from a detailed consideration of the mineralogical and inorganic chemical compositions of the deposits, employing recent advances in the use of sedimentary tracers to reconstruct variable sediment sources, texture, redox changes, and palaeoproductivity.

\section{Materials and Methods}

Core MD $84641\left(33^{\circ} 02^{\prime} \mathrm{N}, 32^{\circ} 38^{\prime} \mathrm{E}\right.$; $1375 \mathrm{~m}$ water deptl) was collected during the Noë cruise of the RV Marion Dufresne in August, 1984. Separate samples were taken for foraminiferal isotopic and for chemical and mineralogical analyses. Sampling was at $10 \mathrm{~cm}$ intervals in the marl sections of the core and at $2 \mathrm{~cm}$ intervals through the sapropels. The foraminiferal isotope stratigraphy used here is taken from Fontugne and Calvert [1992]. Dried $\left(60^{\circ} \mathrm{C}\right)$, powdered subsamples were used for mineralogical and chemical analysis. Organic carbon, total nitrogen and carbonate $C$ determinations at the University of British Columbia (UBC) were carried out by a combination of combustion/gas chromatography (total $\mathrm{C}$ and $\mathrm{N}$ ) and coulometry (carbonate $\mathrm{C}$ ); the precisions determined on replicate subsamples were $\pm 1.25 \%$ and $\pm 3.5 \%$ for total $C$ and $N$ and $\pm 2 \%$ for carbonate. Organic carbon values were derived by difference with a combined precision of $\pm 2.35 \%$. Organic $C$ determinations at Gif-sur-Yvette were made by combustion followed by coulometric determination of the evolved $\mathrm{CO}_{2}$ of subsamples that were soaked in $10 \% \mathrm{HCl}$ ovemight and dried to constant weight at $80^{\circ} \mathrm{C}$. Absolute precision was better than $0.1 \%$. Differences between the two organic carbon data sets were generally less than $\pm 5 \%$. Separate subsamples were used for major and minor element determinations by $\mathrm{X}$-ray fluorescence spectrometry, using methods described by Calvert [1990]. Precisions of the analyses were $\pm 3 \%$ for the major elements and $\pm 5 \%$ for the minor elements. The mineralogy of the bulk samples and the clay fraction ( $<2 \mu \mathrm{m}$; separated by settling/centrifugation) was determined by conventional powder X-ray diffractometry. Relative abundances of clay, quartz, low-Mg calcite and high- $\mathrm{Mg}$ calcite in the bulk sediments were determined using the ratios of the peak intensities at 450 (common to all clay minerals), 426 , 303 , and $298 \mathrm{pm}$, respectively. Clay mineral abundances (smectite (ethylene glycol treatment), illite, kaolinite, chlorite, and palygorskite) of selected horizons within sapropels and above and below these intervals were determined from the ratios of their peak areas on X-ray diffraction (XRD) spectra. No significant variations in clay mineral crystallinity were detected.

\section{Results and Discussion}

\subsection{Sapropel Stratigraphy}

Core MD 84641 is located on the northern extremity of the Nile Cone between Cyprus and the Nile Delta. It consists of 11.61

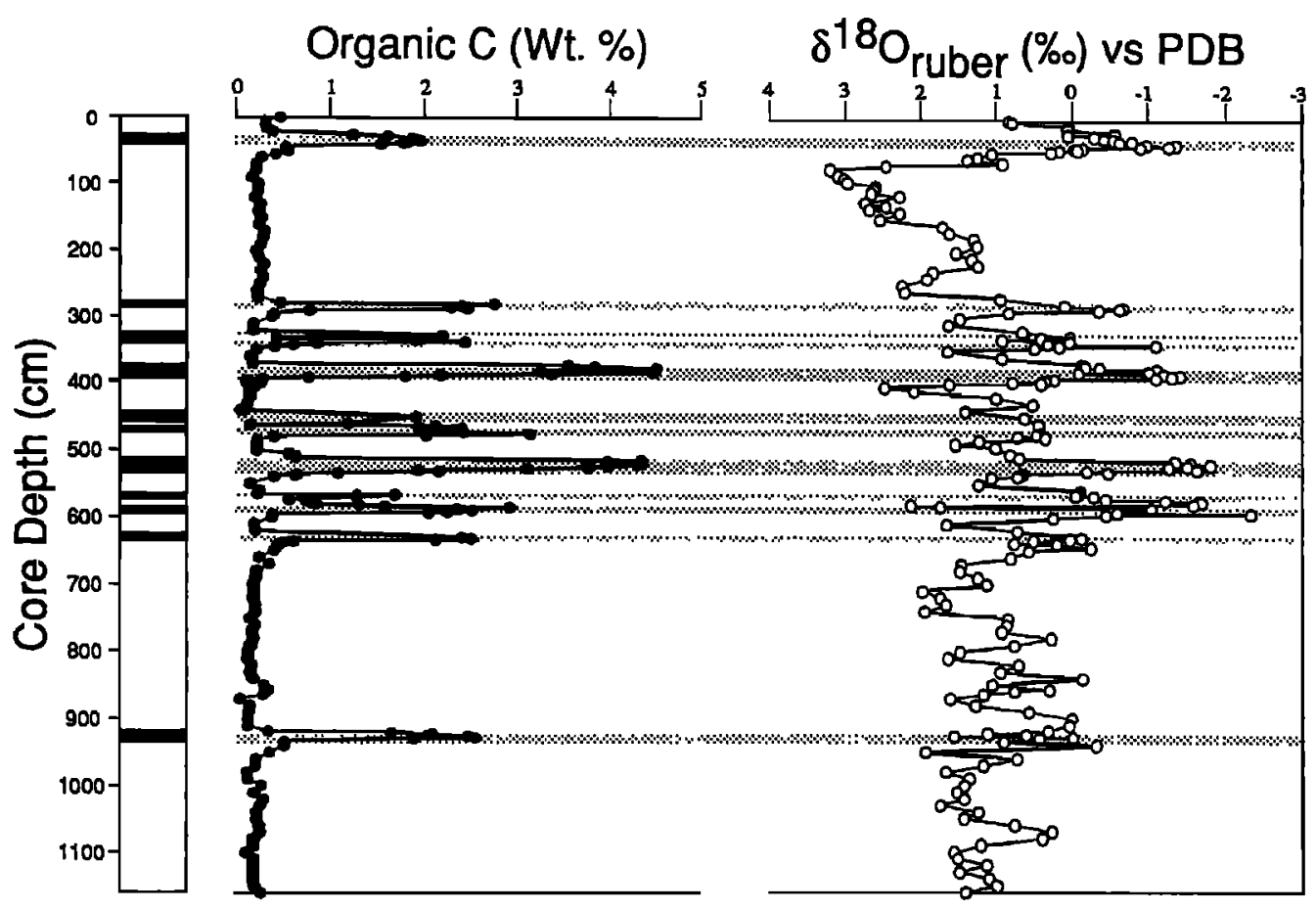

Figure 1. Down core variation of organic carbon concentrations and the $\delta^{18} \mathrm{O}$ (Globigerinoides ruber) stratigraphy of core MD 84641. 


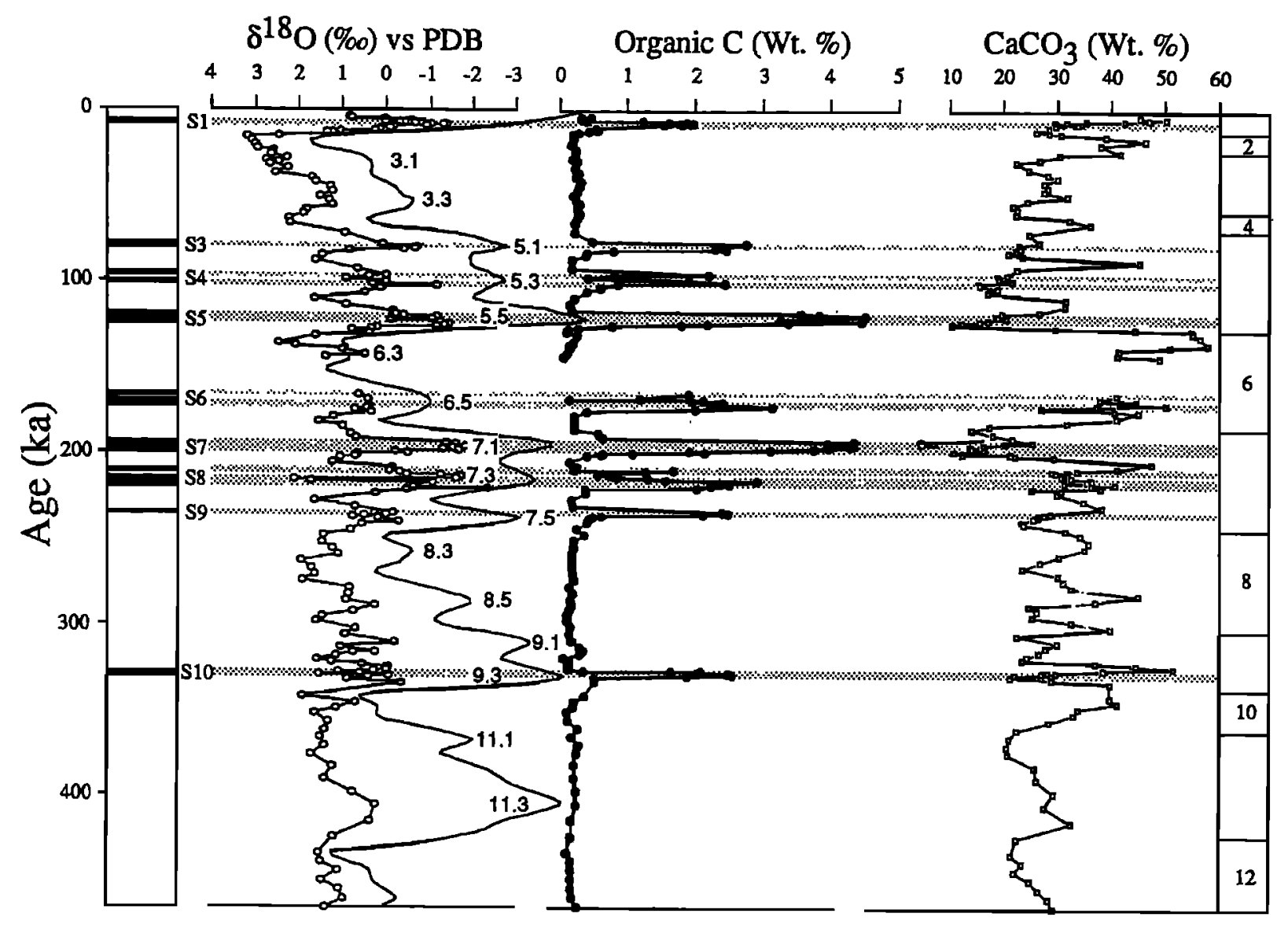

Figure 2. Age model for the core, showing a comparison of the $\delta^{18} \mathrm{O}_{\text {ruber }}$ stratigraphy and the SPECMAP stack [Martinson et al., 1987a] plotted against age, sapropel stratigraphy based on the age model for the core, and down core $\mathrm{CaCO}_{3}$ variations. The SPECMAP curve, with events identified, has been offset to lighter values for ease of viewing the two isotope curves.

$m$ of pale cream to yellowish brown nanofossil/foraminiferal marl ooze (hereinafter referred to as marl) with nine olive green sapropels varying in thickness from 6 to $22 \mathrm{~cm}$ (Figure 1). A hiatus at $445 \mathrm{~cm}$ depth is marked by a subtle change in the color and an abrupt change in water content. Four of the sapropels (those at 328-341, 374-393, 458-479.5, and 578-596 cm) contain gray mud layers with lower organic carbon contents, producing two maxima in organic carbon content at each level.

The chronostratigraphy of the core is based on the Globigerinoides ruber $\delta^{18} \mathrm{O}$ record (Figure 1 ), ${ }^{14} \mathrm{C}$ dating of planktonic foraminifera in the upper $135 \mathrm{~cm}$ of the core, and palaeomagnetic reversal stratigraphy. The radiocarbon age of the uppermost sapropel is $6869-8570$ years B.P. [Fontugne et al., 1994] and is therefore $S 1$ [Troelstra et al., 1991]. The reservoircorrected calendar ages [Bard et al, 1998] are 7463 to 9491

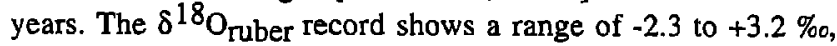
consistent with other foraminiferal records from the Mediterranean that all show a much larger glacial/interglacial range than that in the Atlantic [Vergnaud-Grazzini et al., 1977]. Correlation with the SPECMAP stack [Imbrie et al., 1984; Martinson et al., 1987b] using the AnalySeries software [Paillard et al., 1996] shows that the record in this core extends back to stage 12 (Figure 2). The $\delta^{18} \mathrm{O}_{\text {ruber }}$ record suggests that the hiatus at $445 \mathrm{~cm}$ represents $20 \mathrm{kyr}$ of sedimentation [Kallel et al., 2000]. The Last Glacial Maximum (stage 2) has $\delta^{18} \mathrm{O}$ values higher than $3 \%$, whereas stage 8 has values close to $2 \%$. The lightest $\delta^{18} \mathrm{O}$ values are found in stage 7 .

Comparison of the organic carbon and $\delta^{18} \mathrm{O}_{\text {ruber }}$ records (Figure 2) demonstrates that core MD 84641 contains sapropels S1 and S3-S10 [Cita et al., 1977] or Si2, Si8-Si12, Si16-Si22, and Si30 using the proposed insolation-based numbering scheme of Langereis et al. [1997]. Sapropel S2 (Si4/6) appears to be missing, as is often the case [Rossignol-Strick, 1985] for this poorly developed interglacial stage. (Other missing sapropels in this core will be discussed subsequently.) The magnetic reversal Blake Event (beginning at 117 kyr B.P.) occurs between S4 (Si10) and S5 (Si12) [Tucholka et al., 1987; Fontugne and Calvert, 1992], consistent with the isotope stratigraphy.

Apart from S6 (Si16), the sapropels occur in interglacial stages, there being three such horizons in stages 5 and 7, where there are three prominent interstadials. The grouping of sapropels into clusters has been noted previously by Hilgen [1990], who proposed that individual sapropels are directly related to minima in the precession index, and the clusters of sapropels are related to eccentricity. The organic-poor sections in sapropels $\mathrm{S} 4$ ( $\mathrm{Si10}$ ) and $S 8(\mathrm{Si20})$ correspond with heavy $\delta^{18} \mathrm{O}$ intervals in these warm 


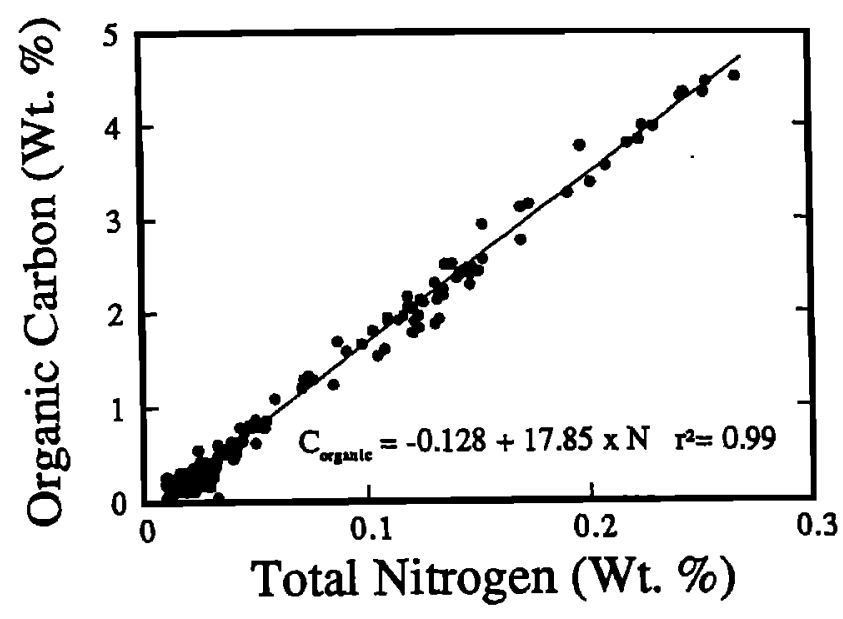

Figure 3. Relationship between organic carbon and total nitrogen concentrations in the core. The slope of the regression indicates the average ratio for the entire sample set; correction of the nitrogen values for the small amount of inorganic nitrogen present (shown by the intercept on the $x$ axis) would produce a zero intercept, indicating that the organic $\mathrm{C} / \mathrm{N}$ is roughly the same in the sapropels and the marls.

interstadials (Figure 2), emphasizing the close relationship between the occurrence of sapropels and climate in the eastern Mediterranean. In the case of S6 (Si16), $\delta^{18} \mathrm{O}$ does not change across the organic-poor section.

The age model for this core yields sedimentation rates of between 1.3 and $5.3 \mathrm{~cm} / \mathrm{kyr}$. These are similar to those reported for this part of the eastein Mediterranean [Stanley and Maldonado, 1977]

\subsection{Organic Carbon and Carbonate}

Organic carbon contents of the sapropels range from 2 to 4.5 wt \% (Figures 1 and 2). Intercalated gray mud layers with lower organic carbon contents in S4 (Si10), S6 (Si16), and S8 (Si20) produce two maxima in organic carbon content at each horizon. The marls have organic carbon contents ranging from 0.1 to 0.3 wt $\%$, with no systematic trends in this lithology down the core. The $C_{\text {organic }} / \mathrm{N}_{\text {total }}$ ratio is higher in the sapropels (16.92 \pm 1.1 ), defined as those horizons with $>1 \%$ organic $\mathrm{C}$, compared with the marls ( $12.34 \pm 4.1$ ), a difference that is significant at the $<1 \%$ level (two-sided $t$ test). However, this difference is caused by the presence of a small amount of inorganic nitrogen in all samples, reflected in the intercept of the regression in Figure 3. Thus organic-poor samples have lower than average $\mathrm{C}_{\text {organid }} / \mathrm{N}$ ratios, and organic-rich samples have higher than average $\mathrm{C}_{\text {organic }} / \mathrm{N}$ ratios. Correction for the nitrogen fraction indicated by the intercept would produce a similar average $\mathrm{C}_{\text {organic }} \mathrm{N}$ ratio in both lithologies.

Calcium carbonate values have been estimated from the carbonate carbon determinations, assuming no phase other than calcite or aragonite is present (but see below). The concentrations range from 10 to $58 \%$ by weight and have minima just below or within all sapropels (Figure 2). The highest values occur in the upper part of stage 6 , and this is followed by an abrupt change to the lowest values in the overlying sapropel S5 (Si12). High carbonate values also occur slightly above $S 1$ (Si2), S7 (Si18), and $\mathrm{S} 10(\mathrm{Si} 30)$.

\subsection{Mineralogy}

Core MD 84641 contains variable proportions of quartz, feldspar, calcite, magnesian calcite, aragonite, smectite, illite, and kaolinite and minor chlorite, dolomite, and palygorskite. The

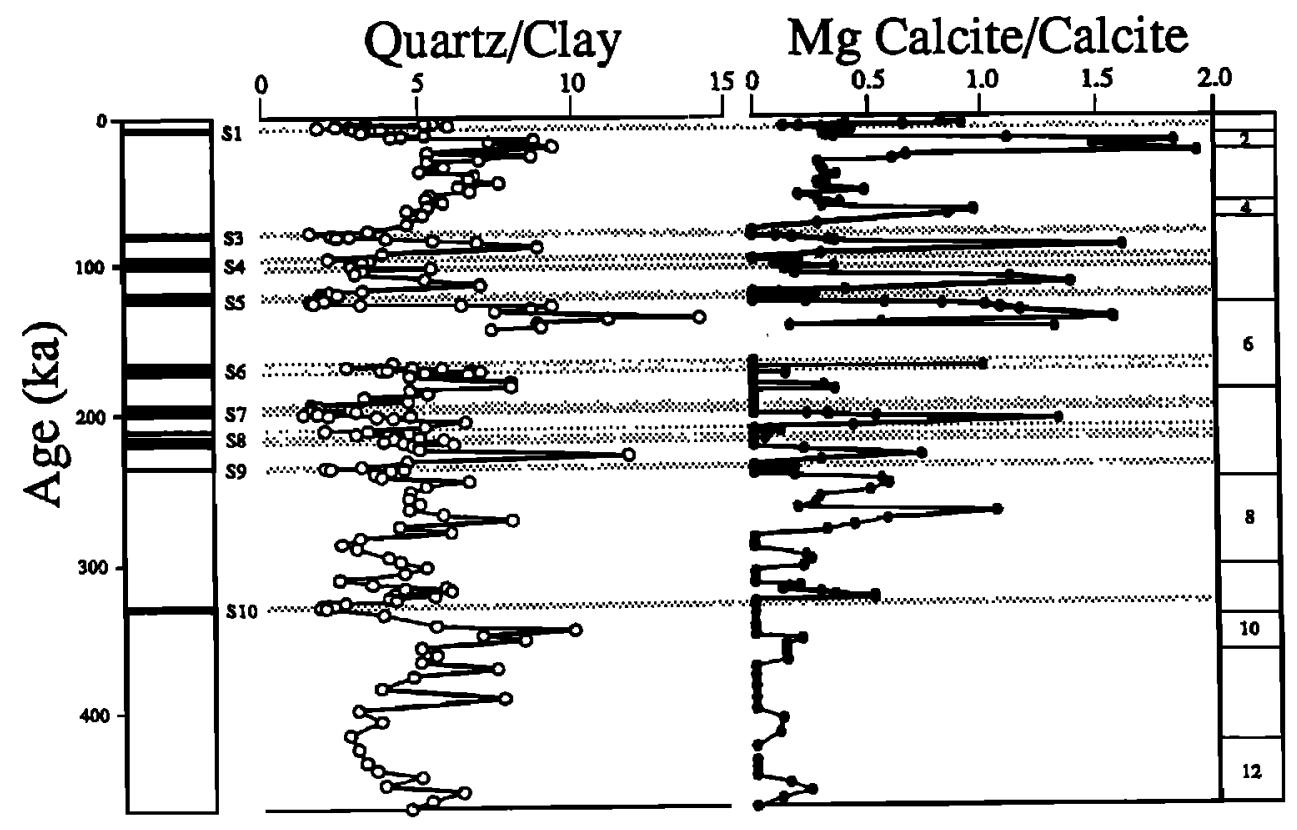

Figure 4. Down core distributions of the relative abundances of quartz and high-Mg calcite, expressed as the peak height ratios quartz/clay and high-Mg calcite/low-Mg calcite on X-ray diffractograms. 
relative abundances of the principal phases show that the bulk composition of the sapropels and the marls differ significantly. Thus quartz/clay ratios are systematically lowest within and highest below each sapropel (Figure 4); furthermore, short-lived abrupt changes in this ratio occur throughout the core. The higher quartz contents of the marls signify that those intervals are coarser grained, whereas quartz/clay minima in the sapropels indicate that they consist of the finest grain sizes of the entire core.

In addition to high abundances of low-magnesian calcite, typical of foraminifera and coccoliths, there are also large changes in the abundance of high-magnesian calcite in the core (Figure 4). The spacing of the distinct $\mathrm{d}_{211} \mathrm{Mg}$ calcite peak indicates that the $\mathrm{Mg}$-rich phase contains $-16 \mathrm{~mol}^{\circ} \mathrm{MgCO}_{3}$ [Goldsmith and Graf, 1958; Milliman and Müller, 1973]. Concentrations of this phase exceed those of low-Mg calcite in many of the marl sections of the core. The lowest values are found within the sapropels, where this phase is commonly undetectable using the powder diffraction method employed.

The sapropels have higher smectite and kaolinite and lower illite and palygorskite contents than the marls. Illite is the dominant clay mineral in the western part of the eastern Mediterranean, whereas smectite is dominant in the eastern part of the basin [Chamley, 1972; Dominik and Stoffers, 1978]. The high proportion of smectite in the clay fraction of core MD 84641 is attributed to its supply by the Nile [Venkatarathnam et al., 1972; Stanley and Liyanage, 1986], and the higher content of kaolinite is probably due to its derivation from arid source areas in northem Africa [Foucault and Mélières, 2000]. Sapropels in the Bannock Basin in the central Ionian Sea also have much lower kaolinite/chlorite ratios (due to significantly higher chlorite contents) and lower palygorskite contents than the associated sediments [Tomadin and Landuzzi, 1991]. Palygorskite characteristically forms in arid, saline soils that are typical of the circum-Mediterranean region [Singer, 1985]. It is presently transported over the central Mediterranean by winds blowing from southern sources [Tomadin et al., 1984]. The lower abundance or the complete absence of this phase in the sapropels suggests that arid source areas were less extensive or wind strength was lower during times of sapropel formation.

\subsection{Chemical Composition}

Because the sapropels and marls in core MD 84641 have different and highly variable contents of organic matter and carbonate (Figure 2), which dilute the detrital fraction to variable extents, the compositions of the two facies have been compared by normalizing the major element contents to $\mathrm{Al}$, a reliable index of fine-grained aluminosilicate detritus in terrigenous-bearing sediments [Calvert, 1976]. Minor element data from core MD 84641 support the conclusions that can be drawn from the major element variations, indicating that most of the $\mathrm{Al}$ is indeed contributed to the eastern Mediterranean within aluminosilicate detritus.

The down core distributions of $\mathrm{Si} / \mathrm{Al}, \mathrm{Ti} / \mathrm{Al}$, and $\mathrm{K} / \mathrm{Al}$ are generally coherent, although $\mathrm{Ti} / \mathrm{Al}$ behaves differently in some intervals (Figure 5). This coherence is consistent with the lack of significant biogenous opal in the core, a common observation in the eastern Mediterranean [Kemp et al., 1999], which would otherwise cause variations in $\mathrm{Si} / \mathrm{Al}$ ratios without affecting $\mathrm{Ti} / \mathrm{A}]$ and $\mathrm{K} / \mathrm{Al}$. Minima in all three ratios characterize the sapropels, and there are also prominent minima in stages 8 and 9 and smaller relative minima in stages 3 and 6 where sapropels do not occur.

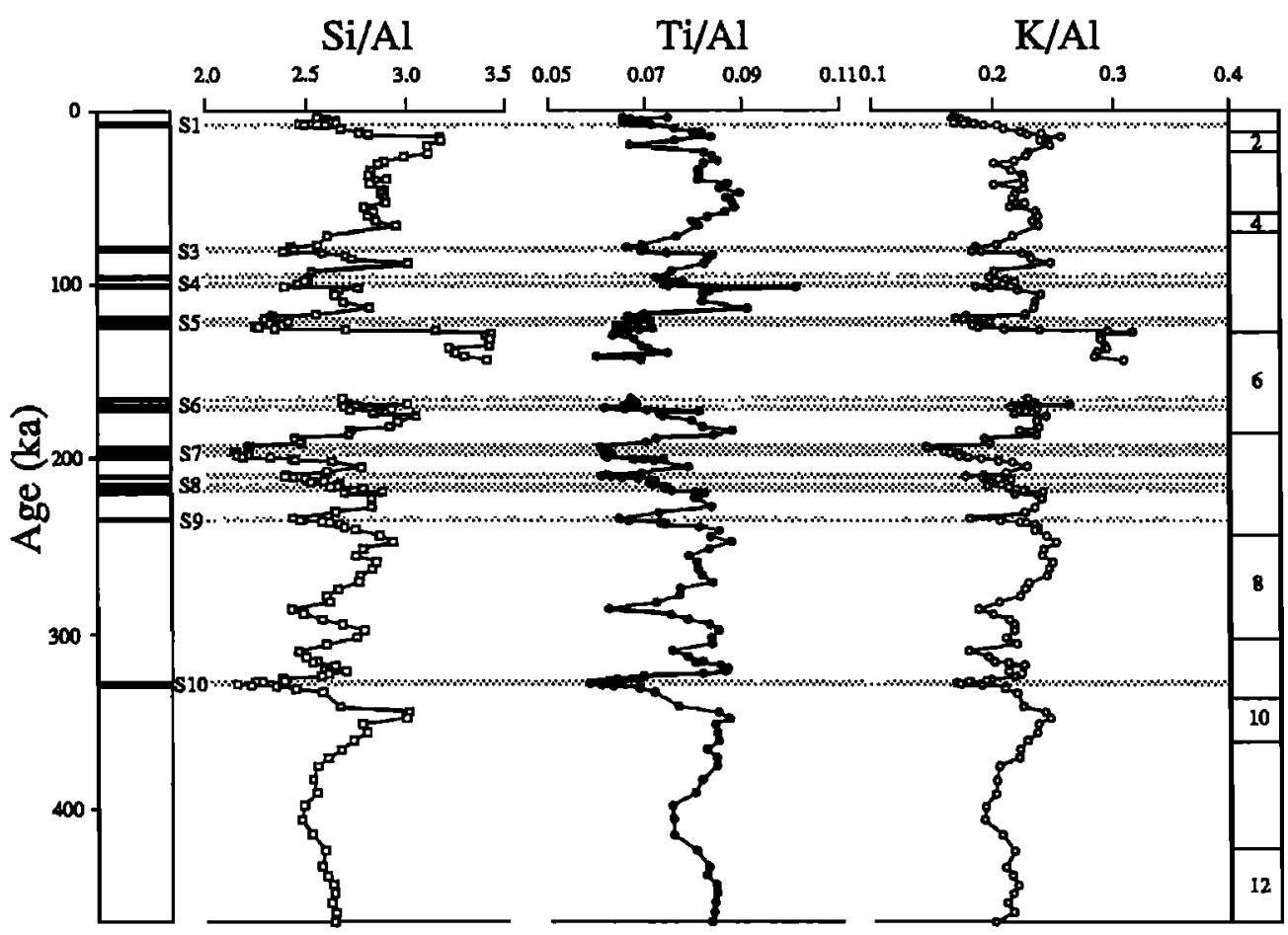

Figure 5. Down core distributions of Si/Al, Ti/Al, and K/Al. Ratios show distinct minima in all sapropels (apart from $\mathrm{K} / \mathrm{Al}$ in S6) and between $\mathrm{S} 1$ and $\mathrm{S} 3$ and between $\mathrm{S} 9$ and $\mathrm{S} 10$. 


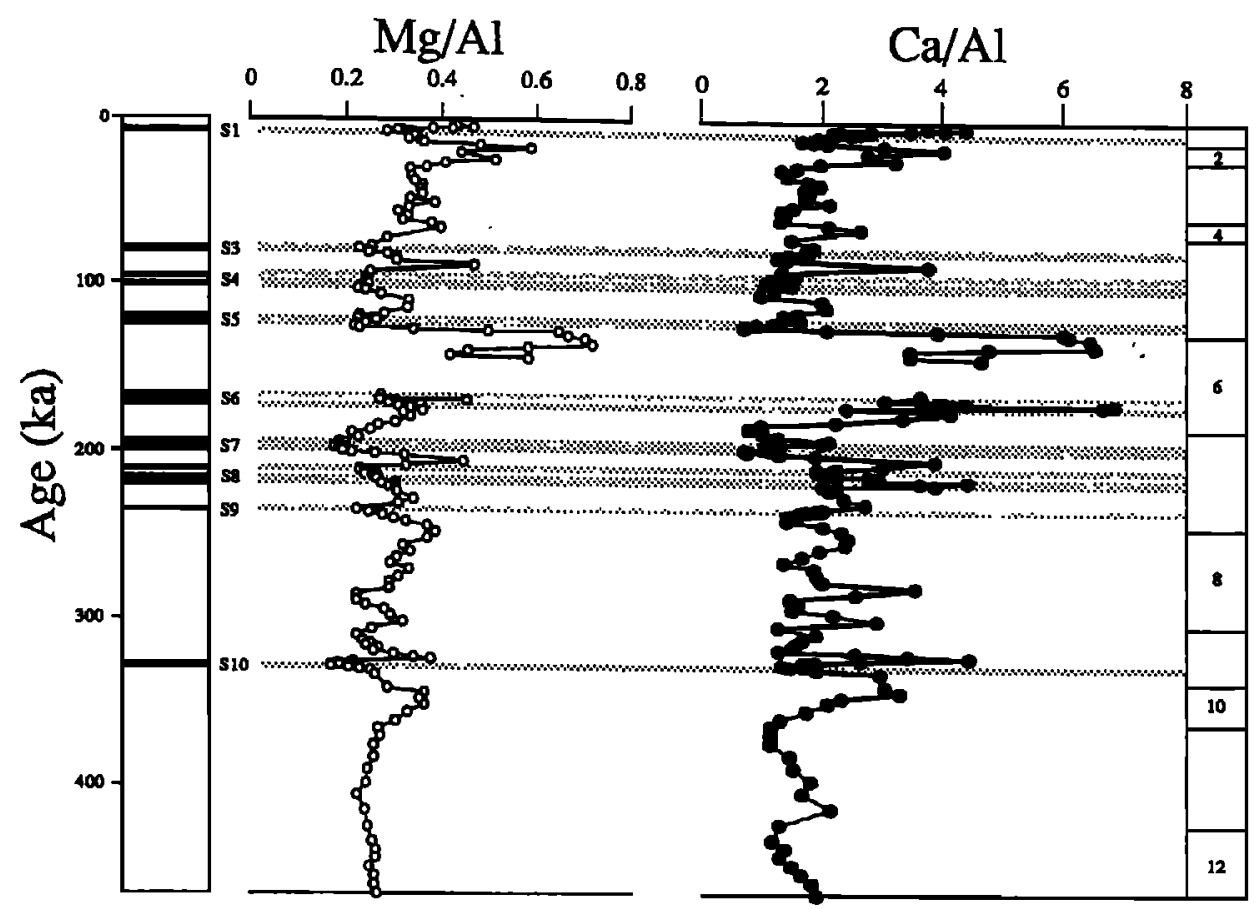

Figure 6. Down core distributions of $\mathrm{Mg} / \mathrm{Al}$ and $\mathrm{Ca} / \mathrm{Al}$ ratios. The distributions are highly coherent, minima occurring in all sapropels except $S 6$.

Sapropel S6 (Si16) has much higher $\mathrm{Si} / \mathrm{Al}$ and $\mathrm{K} / \mathrm{Al}$ ratios, and all three ratios are higher in the lower part of S8 (Si20) compared with the other sapropels. The major difference between the distributions of $\mathrm{Si} / \mathrm{Al}$ and $\mathrm{K} / \mathrm{Al}$, on the one hand, and $\mathrm{Ti} / \mathrm{Al}$, on the other, is in the location of the highest values. For $\mathrm{Si} / \mathrm{Al}$ and $\mathrm{K} / \mathrm{Al}$ the maximal values are found below S5 (Si12) where Ti/Al ratios are very low, whereas the highest $\mathrm{Ti} / \mathrm{Al}$ values are between S4 (Sil0) and S5 (Si12).

These variations are probably due to bulk mineralogical changes, $\mathrm{Si} / \mathrm{Al}$ varying with quartz content, $\mathrm{K} / \mathrm{Al}$ varying with the abundance of $\mathrm{K}$-feldspar and illite, and Ti/Al reflecting the relative abundance of Ti-bearing heavy minerals, such as ilmenite, sphene, etc. $\mathrm{Si} / \mathrm{Al}$ and $\mathrm{K} / \mathrm{Al}$ ratios are high where quartz/clay ratios are high (Figure 4). Thus, the Si/Al and $\mathrm{K} / \mathrm{Al}$ ratios can be used as sensitive indices of the relative abundance of quartz and $\mathrm{K}$-feldspar, respectively, and can be used as an indirect measure of sediment texture. The coarsest sediment (highest $\mathrm{Si} / \mathrm{Al}$ and $\mathrm{K} / \mathrm{Al}$ ) occurs immediately below S1 (Si2), S5 (Si12), and $\mathrm{S} 10$ (Si30). Ti/Al ratios are low in stage 6 between S5 (Si12) and $\mathrm{S} 6$ ( $\mathrm{Si} 16$ ), where $\mathrm{Si} / \mathrm{Al}$ and $\mathrm{K} / \mathrm{Al}$ ratios indicate the presence of coarse-grained material. The Ti-bearing heavy minerals may well be somewhat finer grained (although still coarser than the clay fraction) than quartz and feldspar, accounting for the differences in the locations of the Ti/Al and the $\mathrm{Si} / \mathrm{Al}$ and $\mathrm{K} / \mathrm{Al}$ peaks (Figure 5).

The distribution of $\mathrm{Mg} / \mathrm{Al}$ ratios (Figure 6) is very similar to that of $\mathrm{Si} / \mathrm{Al}$ and $\mathrm{K} / \mathrm{Al}$ (Figure 5). Thus the values are lowest in all sapropels except S6 (Si16) and are highest in stages 2 and 6; prominent minima also occur in stages 8 and 9 , where $\mathrm{Si}$, $\mathrm{Ti}$, and $\mathrm{K}$ are all low relative to $\mathrm{Al}$. This could be due to the covariation of a $\mathrm{Mg}$-bearing detrital aluminosilicate, such as chlorite or palygorskite, with quartz and feldspar. However, Mg-bearing aluminosilicates, although present, are relatively minor constituents of the marls, and comparison of Figures 4 and 6 shows that the down core changes of high- $\mathrm{Mg}$ calcite and $\mathrm{Mg} / \mathrm{Al}$ ratios are highly coherent. In view of the relative abundance of low- and high-Mg calcite (Figure 4) and the Mg content of the latter phase, it can be shown by calculation that the distribution of $\mathrm{Mg}$ is significantly controlled by the abundance of high- $\mathrm{Mg}$ calcite, which largely obscures any variability in aluminosilicate content. Down core trends in $\mathrm{Ca} / \mathrm{Al}$ ratios are coherent with those of $\mathrm{Mg} / \mathrm{Al}$ (Figure 6), reflecting the dominant control of the total Ca content by carbonate phases.

Fine-grained and nodular high-Mg calcite is common in the eastern Mediterranean [Olausson, 1961], where it occurs as roughly $6 \mathrm{~mm}$ diameter microcrystals in the marls but not in the sapropel horizons and also as nodules and cemented crusts on seamounts and on the deep basin floor [Fischer and Garrison, 1967; Milliman and Müller, 1973; Müller and Fabricius, 1974]. It is also abundant in cores from the Aegean Sea [Aksu et al., 1995]. Because of its abundance (up to $75 \mathrm{wt} \%$ ) and mode of occurrence it is probably formed inorganically in the surface sediments [Milliman and Muiller, 1973], and its precipitation in the eastern basin is due to the prevailing high bottom water salinities. This phase also occurs in the Red Sea [Gevirtz and Friedman, 1966; Milliman et al., 1969], where its presence has been attributed to high salinity conditions. Its occurrence in the marls in MD 84641 and its absence in the sapropels suggests that bottom water as well as surface water [Thunell and Williams, 1989] salinities were higher during the deposition of the marls. Other minima in the abundance of high-Mg calcite (Figure 4) where sapropels are absent and where Si/Al, $\mathrm{K} / \mathrm{Al}$, and $\mathrm{Ti} / \mathrm{Al}$ are also low, notably in stages 3,8 , and 9 , will be discussed in section 3.5. 


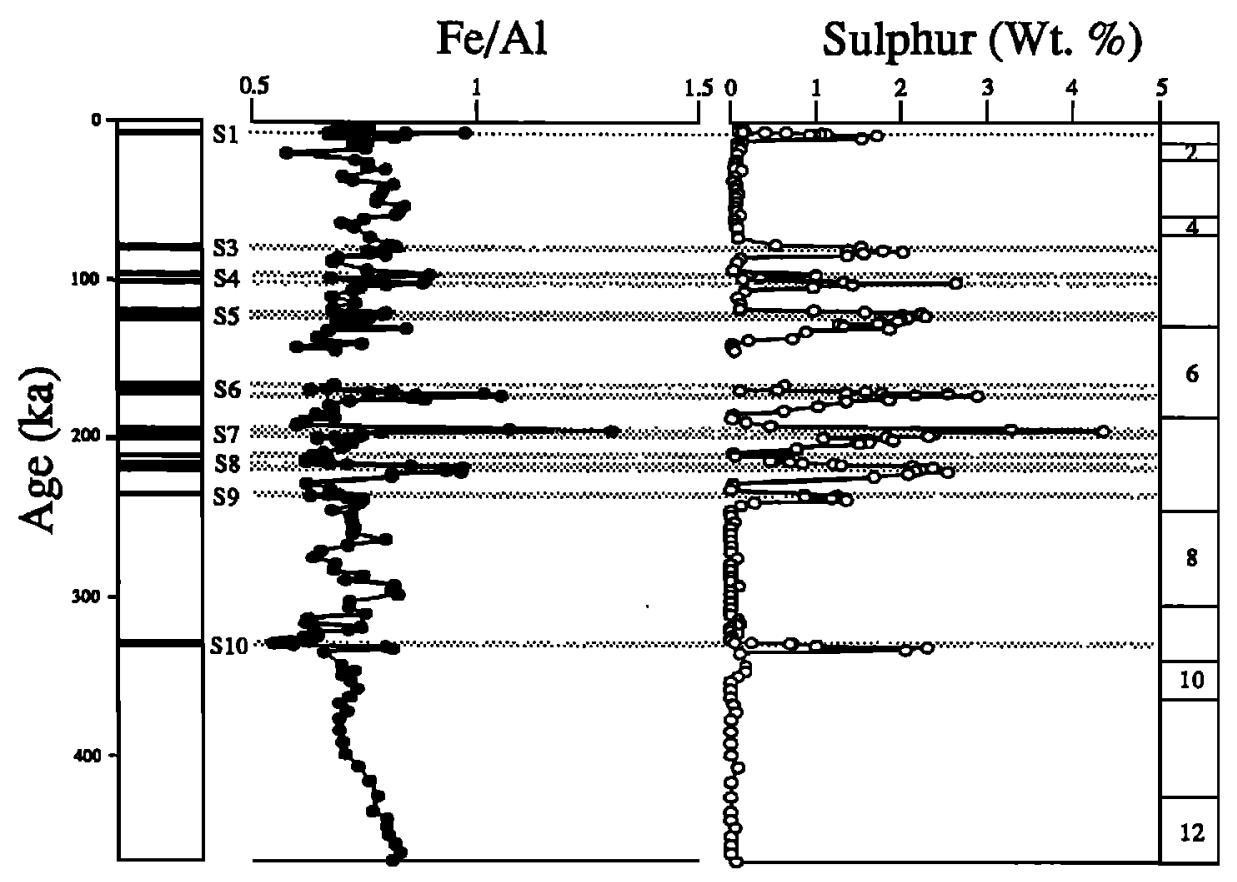

Figure 7. Down core distributions of $\mathrm{Fe} / \mathrm{Al}$ and wt $\% \mathrm{~S}$. The latter occurs predominantly as pyrite.

The distribution of $\mathrm{Fe} / \mathrm{Al}$ ratios (Figure 7) shows that $\mathrm{Fe}$ enrichments characterize many of the sapropels; however, S5 (Si12), the upper part of S6 (Si16), and S9 (Si22) have very small enrichments. Sapropel $\mathrm{S} 10$ ( $\mathrm{Si30}$ ) has higher $\mathrm{Fe} / \mathrm{Al}$ in the lower part and very low values in the upper part. Much of the variation in the abundance of $\mathrm{Fe}$ in MD 84641 is probably controlled by the distribution of pyrite, as reflected in the distribution of total sulphur (Figure 7), which ranges from 0.01 to $4.35 \%$ by weight and is highest in the sapropels. There are also relatively high $S$ concentrations just below many of the sapropels due to the downward diffusion of sulphide from the anoxic organic-rich horizons and its reaction with reduced Fe diffusing from deeper levels in the sediment [Passier et al., 1999]. Relative Fe contents are much less variable in the marls, and $\mathrm{Fe} / \mathrm{Al}$ is slightly lower in stages 2,4 , and 6 , and the middle of stage 8 , possibly indicating some variability in the nature of the detrital Fe-bearing aluminosilicate minerals in the core.

Variability in the minor element composition of the sapropels and associated sediments in core MD 84641 supports the interpretation of down core changes in bulk sediment composition and additionally provides information on changes in palaeoproduction and redox conditions. Thus the distribution of Sr closely follows that of $\mathrm{Ca}$. Highest concentrations are found where $\mathrm{CaCO}_{3}$ is highest, namely immediately below S5 (Si12) and $\mathrm{S} 6$ ( $\mathrm{Si} 16)$ and in stage 1, whereas the lowest $\mathrm{Sr} / \mathrm{Al}$ values are found in the sapropels S5 (Si12) and S7 (Si18) (Figure 8). This reflects the distribution of biogenous calcite, in which $\mathrm{Sr}$ substitutes for $\mathrm{Ca}$ up to values of 1200-1500 ppm [Turekian, 1964; Thompson and Bowen, 1969], and of high-Mg calcite. Strontium concentrations in the latter, inorganic phase are likely to be lower than in biogenous carbonate phases, but we are not able to determine this partitioning because it was not possible to separate the very fine grained inorganic and biogenous (coccolith) materials. This conjecture is supported by the lack of significant difference in the projected $\mathrm{Sr}$ content at $100 \% \mathrm{CaCO}_{3}$ in the sapropels and the marls.

Rubidium and $\mathrm{Zr}$ in the core are controlled entirely by the composition and grain size of the aluminosilicate fraction. Rubidium substitutes for $\mathrm{K}$ in most $\mathrm{K}$-bearing minerals, so the distribution of these two alkali metals parallels each other down core (Figures 5 and 8); the lowest values are found in many of the sapropels, and the highest $\mathrm{Rb} / \mathrm{Al}$ ratios occur in stages 2 and 5 . Sapropels S6 (Si16) and S8 (Si20) show little change in both $\mathrm{Rb} / \mathrm{Al}$ and $\mathrm{K} / \mathrm{Al}$. $\mathrm{Zr} / \mathrm{Al}$ ratios change in concert with changes in $\mathrm{Si} / \mathrm{Al}$ (Figures 5 and 8 ), and values of both ratios are positively correlated. Thus highest $\mathrm{Zr} / \mathrm{Al}$ is found in stage 2 and the upper part of S6, and the lowest values occur in each of the sapropels. Zirconium occurs predominantly in the mineral zircon in marine sediments, which in turn, is normally confined to the finesand/coarse-silt fraction. Variations in $\mathrm{Zr} / \mathrm{Al}$ therefore lend support to the inference from the quartz/clay and $\mathrm{Si} / \mathrm{Al}$ ratios of larger grain sizes in the marl horizons below many of the sapropels.

Somewhat similar contrasts in $\mathrm{Si} / \mathrm{Al}, \mathrm{Ti} / \mathrm{Al}$ and $\mathrm{Zr} / \mathrm{Al}$ ratios between sapropels and marls have been identified in cores from Ocean Drilling Program (ODP) Sites 964 and 967 [Wehausen and Brumsack, 1999], and the same $\mathrm{Ti} / \mathrm{Al}$ and $\mathrm{Zr} / \mathrm{Al}$ patterns occur in Miocene sections from the island of Gavdos, south of Crete [Schenau et al., 1999]. These differences were attributed to variations in the input of fluvial and aeolian detritus to these sites, with finer-grained sediments of fluvial derivation being more important during sapropel deposition and coarser aeolian material being much more important during marl deposition.

The distribution of $\mathrm{Ba} / \mathrm{Al}$ ratios is closely coherent with organic C (Figure 8); most Ba enrichments above crustal abundances (Ba/Al $=-0.0068$ ) [Taylor and McLennan, 1985] occur in the sapropels. In some cases, $\mathrm{Ba}$ is also enriched just above a sapropel, such as S1 (Si2), S3 (Si8), and S6 (Si16), and 


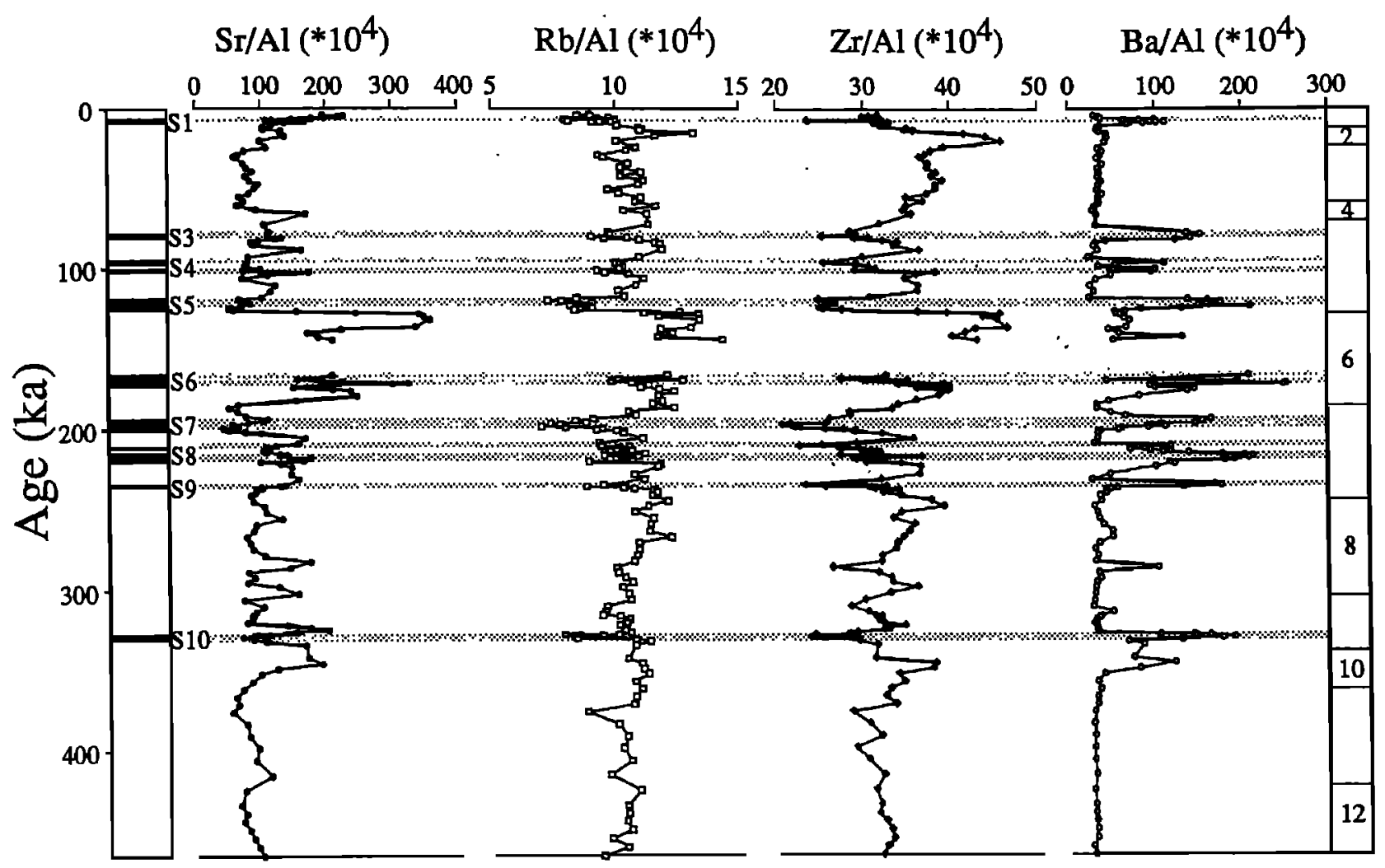

Figure 8. Down core distributions of $\mathrm{Sr} / \mathrm{Al}, \mathrm{Rb} / \mathrm{Al}, \mathrm{Zr} / \mathrm{Al}$, and $\mathrm{Ba} / \mathrm{Al}$. Variations in $\mathrm{Sr} / \mathrm{Al}$ are coherent with those of $\mathrm{Ca} / \mathrm{Al}$ and $\mathrm{Mg} / \mathrm{Al}$, whereas variations in $\mathrm{Rb} / \mathrm{Al}$ and $\mathrm{Zr} / \mathrm{Al}$ follow $\mathrm{K} / \mathrm{Al}$ and $\mathrm{Si} / \mathrm{Al}$, respectively. $\mathrm{Ba} / \mathrm{Al}$ peaks are confined to each of the sapropels but also occur between $\$ 5$ and $\mathrm{S6}$, between $\$ 9$ and $\$ 10$, and below $\mathrm{S6}$ and $\mathrm{S10}$.

there is a prominent $\mathrm{Ba} / \mathrm{Al}$ maximum below $\mathrm{S} 10$ ( $\mathrm{Si30}$ ). The marls have $\mathrm{Ba} / \mathrm{Al}$ ratios of roughly 0.003 upon which the marked enrichments in the sapropels are superimposed. Almost all the Ba in the $\mathrm{S} 1$ sapropel is present as $1-3 \mu \mathrm{m}$ barite crystals [Thomson et al., 1995], similar to its mode of occurrence in open ocean pelagic sediments [Church, 1970; Paytan et al., 1993; Gingele and Dahmke, 1994].

Down core variations in total $\mathrm{Ba}$ abundances record palaeoproductivity variations [Schmitz, 1987], and palaeoproductivity algorithms using total sedimentary $\mathrm{Ba}$ concentrations have been developed [Dymond et al., 1992; François et al., 1995]. Although there has been some minor diagenetic redistribution of $\mathrm{Ba}$ in core MD 84641 [van Os et al., 1991], as seen, for example, below $S 10$ ( $\mathrm{Si30}$ ), the close coherence between $\mathrm{Ba} / \mathrm{Al}$ and organic $\mathrm{C}$ suggests higher production during sapropel formation [Thomson et al., 1999]. Note, in addition, that there are small $\mathrm{Ba} / \mathrm{Al}$ peaks between $\mathrm{S} 9$ ( $\mathrm{Si22}$ ) and $\mathrm{S} 10(\mathrm{Si} 30)$ where $\mathrm{Si} / \mathrm{Al}$ and $\mathrm{Zr} / \mathrm{Al}$ ratios are low.

Low and more or less constant $\mathrm{Mn} / \mathrm{Al}$ ratios occur in the marls, whereas sporadic high values occur at the bases and the tops of several of the sapropels, most notably below S6 (Si16), above and below S10 (Si30), and above S1 (Si2) (Figure 9). Small enrichments are also seen in stages 3.8, and 11. Since manganese in sediments is strongly affected by the redox state of the sediment [Lynn and Bonatti, 1965], the pattern of Mn distribution is controlled almost entirely by postdepositional reaction. Many eastern Mediterranean sapropels have been altered by the downward diffusion of pore water oxygen after the formation of the sapropels ceased and the marl-forming regime was reestablished [de Lange et al., 1989]. The effects of this process are similar to those in organic-rich North Atlantic turbidites [Wilson et al., 1985; Thomson et al., 1993], in that the organic material in the upper part of the sapropel is degraded and redox-sensitive metals and metalloids are redistributed around the downward migrating oxidation front. Sapropels may be completely removed by this process [Higgs et al., 1994]. The details of these effects in the youngest Mediterranean sapropel (S1) have been fully described [Pruysers et al., 1993; Thomson et al., 1995; Van Santwoort et al., 1996].

Several other redox-sensitive trace metals can be redistributed by the processes just described. Thus $\mathrm{Cu} / \mathrm{Al}, \mathrm{Cr} / \mathrm{Al}$, and $\mathrm{Zn} / \mathrm{Al}$ (Figure 9) have down core variations that are poorly correlated with the positions of the sapropels. Isolated single-point peaks in the ratios are found in the marls, some of which are coincident with minima in $\mathrm{Si} / \mathrm{Al}$ and $\mathrm{Zr} / \mathrm{Al}$ (Figures 5 and 8). In the case of $\mathrm{Zn} / \mathrm{Al}$, maxima and minima occur within different sapropels. Down core variations in $\mathrm{Co} / \mathrm{Al}, \mathrm{Ni} / \mathrm{Al}, \mathrm{Mo} / \mathrm{Al}$, and to a lesser extent V/Al (Figure 10) are much more closely related to the sapropel boundaries, maxima most often occurring within these horizons. Some isolated peaks of $\mathrm{Co} / \mathrm{Al}$ and $\mathrm{V} / \mathrm{Al}$ are found in the marls, whereas $\mathrm{Ni} / \mathrm{Al}$ and $\mathrm{Mo} / \mathrm{Al}$ maxima are largely confined to the sapropels; $\mathrm{Ni} / \mathrm{Al}$ begins to increase immediately below some of the sapropels, whereas $\mathrm{Mo} / \mathrm{Al}$ ratios show the best coherence with the boundaries of the sapropels. In addition, $\mathrm{Co} / \mathrm{Al}, \mathrm{Ni} / \mathrm{Al}$, 


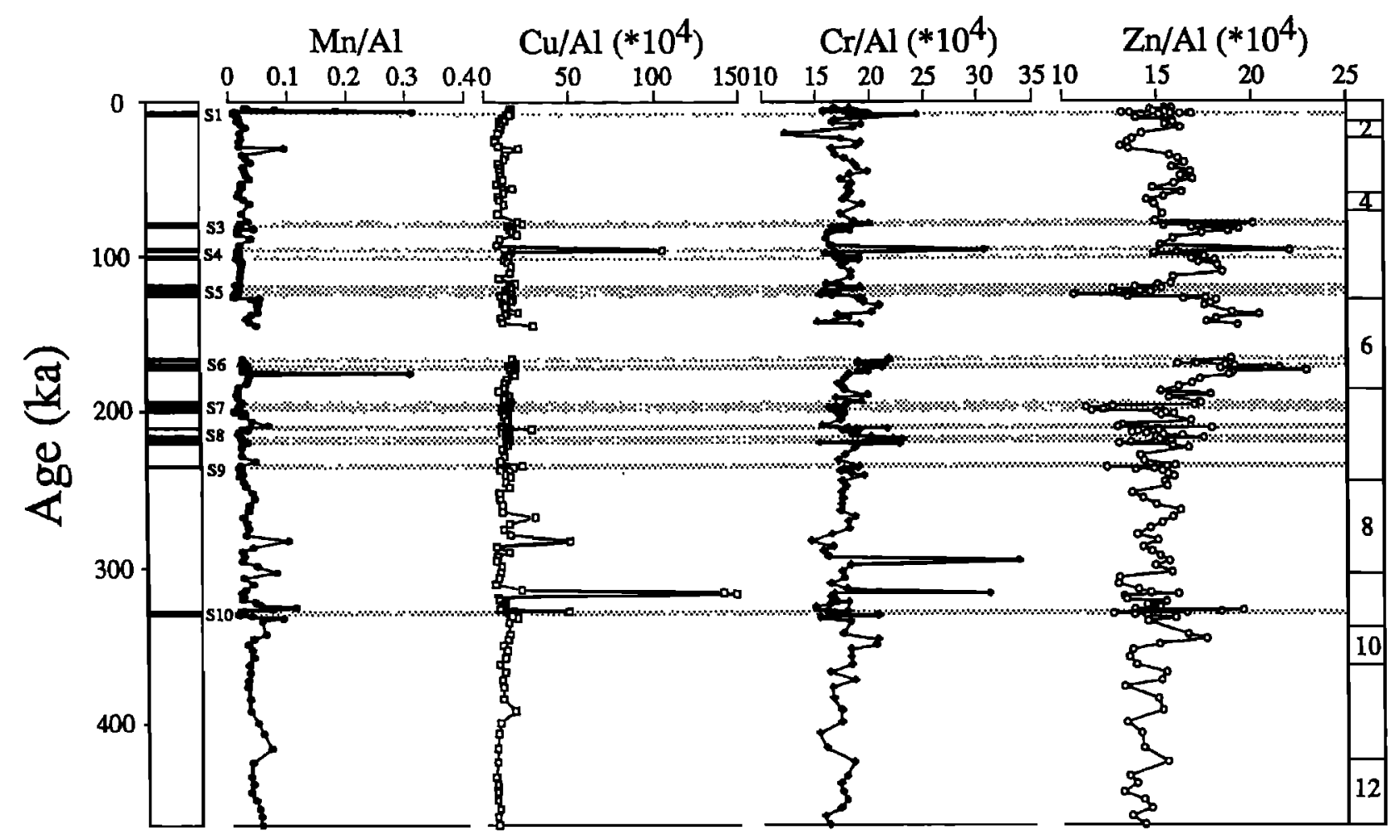

Figure 9. Down core distributions of $\mathrm{Mn} / \mathrm{Al}, \mathrm{Cu} / \mathrm{Al}, \mathrm{Cr} / \mathrm{Al}$, and $\mathrm{Zn} / \mathrm{Al}$. The lack of a clear relationship between the distribution of these ratios and the occurrence of sapropels suggests that postdepositional processes have largely obliterated any signals of changing sedimentary conditions.

and $\mathrm{Mo} / \mathrm{Al}$ ratios are much lower in the upper section of the composite sapropels S4 (Si10), S6 (Si16), and S8 (Si20) than they are above the intercalated organic-poor mud layer.

The enrichment of a wide range of trace metals in the sapropels of core MD 84641 that are removed to bottom sediments under reducing conditions suggests that bottom waters or the interstitial environment of the sediment was oxygendeficient or even sulphidic during their formation. It is not possible to deduce the degree of oxygen deficiency with the elemental data available because it is known that enrichments of many of the same metals can occur by the downward diffusion of a metal from oxic bottom waters into anoxic subsurface horizons [Calvert and Pedersen, 1993]. Other evidence can sometimes be used to infer bottom water anoxia, such as the presence of laminations or the complete absence of benthos [Jorissen, 1999], and both of these indicators can be found in Mediterranean sapropels. However, there are situations where the sapropels contain a benthic foraminiferal fauna, albeit adapted to very low oxygen conditions [Brolsma, 1978; Jorkers, 1984; Oggioni and Zandini, 1987; Vismara Schilling and Coulbourm, 1991], and one must always be cognizant of the fact that fine laminations can be imparted to sediments under oxic conditions by mat-forming diatoms [Kemp and Baldauf, 1993] that have been found in S5 (Si12) [Kemp et al., 1999]. Anoxic bottom water conditions during sapropel formation are also indicated by the sulphur isotopic composition of pyrite in several sapropels [Passier et al., 1999]. In a similar manner to the relatively high bottom oxygen conditions prevailing during the deposition of an upper sapropel section in the Adriatic Sea inferred from the benthic fauna [Rohling et al., 1997], we also infer nonanoxic conditions during the deposition of the upper sections of sapropels S4 (Si 10), S6 ( $\mathrm{Si16}$ ) and $\mathrm{S} 8$ ( $\mathrm{Si20}$ ) in core MD 84641 from the very low $\mathrm{Co} / \mathrm{Al}$, $\mathrm{Ni} / \mathrm{Al}$ and $\mathrm{Mo} / \mathrm{Al}$ ratios and their contrast to the much higher values in the lower sections of the same sapropels.

\subsection{Sapropel-Marl Differences}

Apart from the organic carbon and nitrogen contents, the mineralogical and chemical composition of the sapropels and marls in core MD 84641 shows that the two facies are compositionally distinct. The differences can be summarized as follows:

1. The marls contain abundant high-Mg calcite, whereas the sapropels have much lower or undetectable amounts of this phase.

2. The sapropels are finer grained than the marls, as shown by their lower quartz/clay, $\mathrm{Si} / \mathrm{Al}$, and $\mathrm{Zr} / \mathrm{Al}$ ratios.

3. The fine-grained (clay) aluminosilicate compositions are different, sapropels containing more smectite and kaolinite and marls containing a higher proportion of illite.

4. The sapropels have high concentrations of trace metals that are precipitated under anoxic conditions as their respective sulphides ( $\mathrm{Co}, \mathrm{Mo}$, and $\mathrm{Ni}$ ) or are reduced to their lower oxidation states under low redox conditions and are fixed in the sediment by precipitation of a reduced phase or adsorption onto other solid phases (Mo, V). The distributions of other metals normally found enriched in anoxic conditions $(\mathrm{Cr}, \mathrm{Cu}$, and $\mathrm{Zn}$ ) have been seriously affected by diagenetic redistribution. 


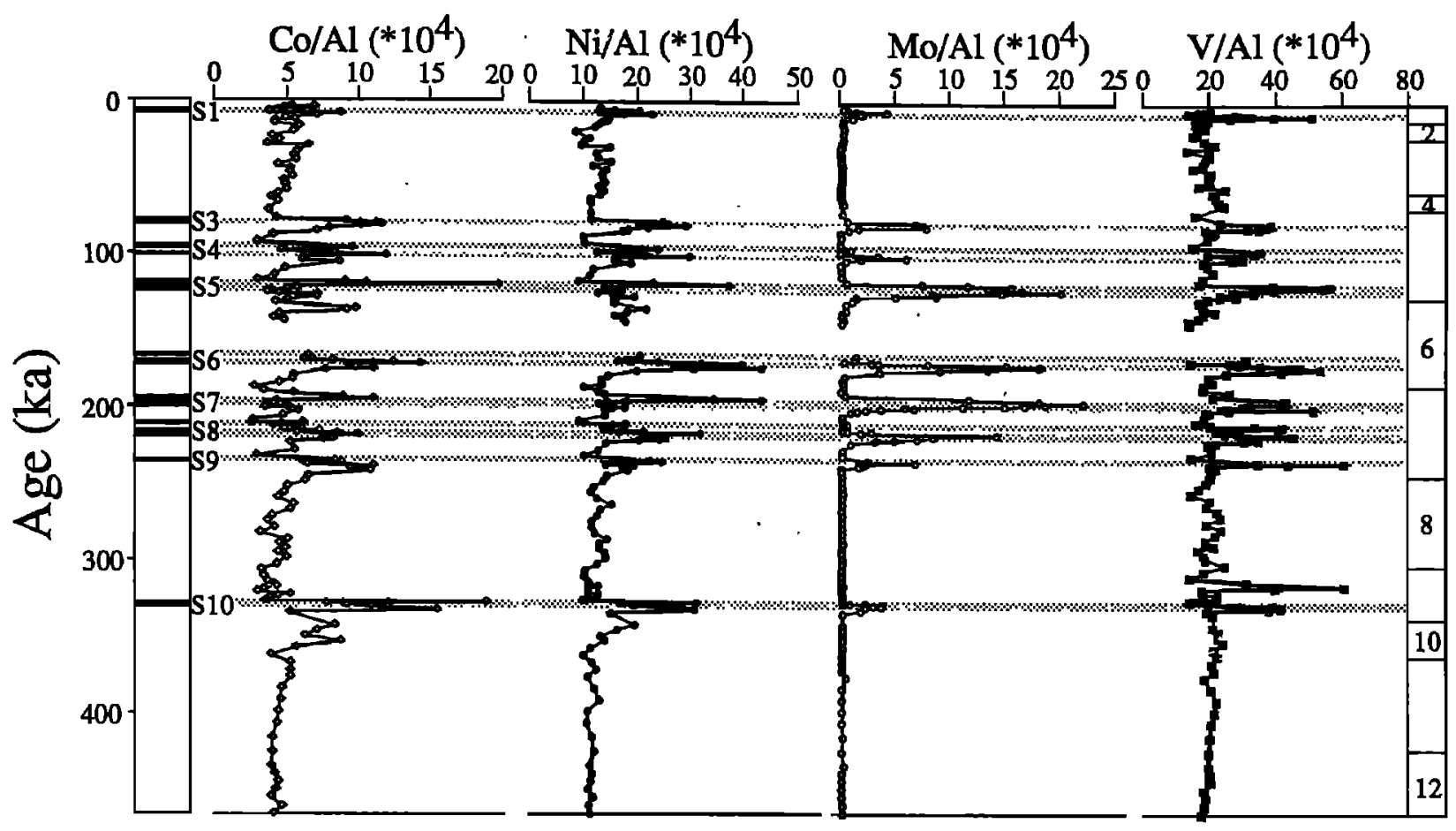

Figure 10. Down core distributions of $\mathrm{Co} / \mathrm{Al}, \mathrm{Ni} / \mathrm{Al}, \mathrm{Mo} / \mathrm{Al}$, and $\mathrm{V} / \mathrm{Al}$. In contrast to the distributions shown in Figure $9, \mathrm{Co}, \mathrm{Ni}, \mathrm{Mo}$, and $\mathrm{V}$ maxima occur in sapropels, apart from $\mathrm{Co}$ in $\mathrm{S} 1$ and $\mathrm{S} 9$ and $\mathrm{V}$ between $\mathrm{S} 9$ and $\mathrm{S} 10$.

5. The sapropels have significantly higher concentrations of Ba compared with the marls.

The differences in the mineralogy and the bulk composition of the terrigenous fraction of the sediments indicate that the source or sources of the sediment in the sapropels and marls were different. Consequently, the sapropel record in core MD 84641 cannot be interpreted simply as the imposition of high organic supply or preservation upon a uniform compositional background. These results are more plausibly interpreted as a change in the conditions of sedimentation and/or sediment delivery, possibly linked to changes in the circulation in the eastern Mediterranean between periods of marl and sapropel formation.

Holocene sediment sources in the eastern Mediterranean are dominated by supply from the Nile and from the southern arid land areas via wind transport [Venkatarathnam and Ryan, 1971; Dominik and Stoffers, 1978]. Thus the fine-grained material in the deep water sediments is dominated by smectite (via the Nile) and kaolinite (from rivers and the deserts via the wind). Illite and chlorite are much more abundant in the western part of the eastem basin, these minerals having a northem source. The higher smectite and kaolinite contents of the sapropels suggest that sediment supply from the southern source was even greater during the deposition of sapropels at the site of core MD 84641 , consistent with the higher flow rates of the Nile at these times [Rossignol-Strick et al., 1982; Rossignol-Strick, 1983; 1985]. This has recently been confirmed from the distribution of ${ }^{87} \mathrm{Sr} /{ }^{86} \mathrm{Sr}$ ratios in the surface sediments of the Levantine Basin [Krom et al., 1999a] and from ${ }^{87} \mathrm{Sr} /{ }^{86} \mathrm{Sr}$ and major element ratios in $\mathrm{S} 1$ (Si2) and associated marls in cores from the same region [Krom et al., 1999b]. These authors showed that the compositional and isotopic data require a simultaneous decrease in Saharan dust input and an increase in Nile River input during the deposition of $\mathrm{S} 1$ (Si2).

As well as having a different clay mineral composition, the marls between each of the sapropels in core MD 84641 are also coarser grained, as shown by the higher quartz/clay, Si/Al, and $\mathrm{Zr} / \mathrm{Al}$ ratios. The highest ratios in the entire core are found immediately below each of the sapropels, especially S1 (Si2) and S5 (12). It is unlikely that hydrodynamic reworking has caused this contrast in view of the water depth at the core site. Because of the distance from fluvial sources, aeolian transport is the most likely transportation agent. At the present time, winds transport large amounts of dust over the eastem and central Mediterranean from the Sahara [Ganor and Mamane, 1982] and from northem sources [Tomadin et al., 1984], and wind transport has been implicated in the distribution of the fine fraction to the sediments of the eastem basin [Venkatarathnam and Ryan, 1971; Tomadin, 1981; Wehausen and Brumsack, 1999]. Thus a more vigorous glacial atmospheric circulation, as generally deduced for the LGM [Petit, 1981; Mahowald et al., 1999] together with a change in the sedimentary source areas suggest that the two sedimentary facies in core MD 84641 reflect different climatic and oceanographic regimes.

The distinct compositional differences between sapropels and marls in MD 84641 provide a means for identifying the positions of so-called missing sapropels. Cita et al. [1977] stated that sapropels S2 (Si4/6) and S4 (Si10) are only "weakly expressed" in cores from the ridge crest of the Ionian Sea and that $S 9$ (Si22) and $\mathrm{S} 10$ ( $\mathrm{Si30}$ ) may be very thin or smeared by bioturbation. Rossignol-Strick, [1985] found that, on the basis of the close relationship between the occurrence of sapropels and African climate changes driven by precessionally forced monsoon 
variability (to be discussed in section 3.7), sapropels should occur at 292 and $314 \mathrm{kyr}$ in the eastern Mediterranean, but they are absent. Thus it appears that there are genuine gaps in the sapropel record in the eastern Mediterranean. Postdepositional "burndown" [de Lange et al., 1989] is one process that could remove a sapropel from the section, thin or relatively organic-poor horizons being especially susceptible [Higgs et al., 1994].

It is necessary to distinguish between situations where sapropels did not form because the climatic conditions did not change sufficiently and situations where such deposits did form but have been completely removed by the burn-down mechanism. In the latter case, horizons of former sapropels are clearly marked by finer sediment grain size and distinctive mineralogy, properties that are not altered by postdepositional oxidation. Thus Figures $4,5,6$, and 8 show that there are prominent minima in quartz/clay, $\mathrm{Mg}$ calcite/calcite, Si/Al, Ti/Al, K/Al, Mg/Al, Rb/Al, and $\mathrm{Zr} / \mathrm{Al}$ ratios, all indicators of sapropel composition, in stages 3,8 , and 9 where there are no organic carbon maxima. The minima that coincide with or lie close to $\mathrm{Ba} / \mathrm{Al}$ peaks, such as between S9 (Si22) and S10 (Si30) (Figure 8), may represent a residual signal of sapropel formation; these are the "ghost" sapropels of other authors. Other minima, notably between S1 (Si2) and S3 (Si8) (Figures 5 and 8), possibly record periods of altered climatic and oceanographic conditions that were insufficient to trigger sapropel formation. These are genuine missing sapropels. The recognition of a reliable conservative tracer of sapropel formation conditions in core MD 84641 provides further insight into the relationship between sapropel formation and palaeoclimatic changes over the last $460 \mathrm{kyr}$, which will be discussed in section 3.7 .

\subsection{Composite Sapropels}

In core MD 84641, sapropels S4 (Si10), S6 (Si16), and S8 (Si20) contain an intercalated horizon of organic-poor sediment; they are therefore composite sapropels [Rohling et al., 1997]. Organic $\mathrm{C}$ concentrations in S6 (Si16) decrease to levels characteristic of the marls, whereas they are significantly higher than the marl values in the organic-poor layers in $\mathrm{S} 4(\mathrm{Si} 10)$ and S8 (Si20) (Figure 2). The $\delta^{18} \mathrm{O}_{\text {ruber }}$ increases significantly in the organic-poor layer in $\mathrm{S} 4$ ( $\mathrm{Si} 10$ ) and $\mathrm{S} 8$ ( $\mathrm{Si20}$ ), whereas there is no significant change in $\mathrm{S} 6$ ( $\mathrm{Sil} 16) . \mathrm{CaCO}_{3}$ contents increase slightly in the organic-poor layer in $\mathrm{S} 8$ ( $\mathrm{Si20}$ ) compared with the sapropelic sediments above and below, whereas there is no significant change in \$4 ( $\mathrm{Si10}$ ) and S6 ( $\mathrm{Si16)}$. High-Mg calcite increases notably in S6 (Sil6), there is a small increase in S4 (Si10), and this phase could not be detected in S8 (Si20) (Figure 4). $\mathrm{Ba} / \mathrm{Al}$ ratios closely track the organic $\mathrm{C}$ changes in the three composite sapropels, whereas $\mathrm{Zr} / \mathrm{Al}$ ratios in the organic-poor layer in each of the composite sapropels are slightly higher compared with the sapropelic sediments above and below this horizon (Figure 8).

The two sections of the composite sapropels have different minor element compositions. Thus, while $\mathrm{Co} / \mathrm{Al}, \mathrm{Ni} / \mathrm{Al}$, and $\mathrm{Mo} / \mathrm{Al}$ ratios all have marked maxima in all sapropels, they remain low in the upper sapropel section of S6 (Si16) and S8 (Si20) (Figure 10); only Mo/Al is much lower in the upper part of S4 (Si10). Since the enrichments of these three metals in the sapropels probably reflect anoxic bottom water and/or interstitial conditions during sapropel formation, the low degrees of enrichment in the upper section of S4 (Si10), S6 (Si16), and S8
(Si20) must be due to somewhat more oxygenated bottom water conditions following the interruption of sapropel deposition. Note that $\mathrm{Ba} / \mathrm{Al}$ ratios are higher than background in both sections of the composite sapropels (Figure 8), suggesting a return to higherproductivity conditions after sapropel formation was interrupted by better bottom water ventilation.

Rohling et al. [1997] described a similar organic-poor horizon in sapropel S1 ( $\mathrm{Si2}$ ) from the Adriatic Sea, and De Rijk et al. [1999] found a possibly coeval layer in the southern Aegean Sea. These authors interpreted high-resolution benthic and planktonic foraminiferal data as reflecting a small sea surface cooling and increased bottom water ventilation that interrupted sapropel deposition at this time. Their data also showed that there was a significant increase in organic carbon flux to the seafloor (ecosystem enrichment) concomitantly with a progressive decrease in bottom water oxygenation for the lower section and more oxygenated bottom water conditions during the deposition of the upper section of the sapropel.

The combined data from MD 84641 suggest that productivity decreased (Ba/Al decreases), salinity increased ( $\mathrm{Mg}$ calcite/calcite increases), wind speed increased ( $\mathrm{Zr} / \mathrm{Al}$ increases), and bottom water and/or interstitial oxygenation increased $(\mathrm{Co} / \mathrm{Al}, \mathrm{Mo} / \mathrm{Al}$, and $\mathrm{Ni} / \mathrm{Al}$ decrease) during the interruption to sapropel S4 (Si10), S6 (Si16), and S8 (Si20) formation. Moreover, bottom water oxygenation remained high during the deposition of the upper sections of these composite horizons even though production returned to the high levels typical of the other noncomposite sapropels in MD 84641. Subtle changes in the hydrological balance during periods when sapropel formation was otherwise favored were evidently responsible for the formation of a number of composite sapropels.

\subsection{Climatic Control of Sapropel Formation}

The formation of the eastern Mediterranean sapropels has been explained by several different models of climatic and/or oceanographic change, and these have been recently reviewed [Rohling and Hilgen, 1991; Rohling, 1994]. All explanations involve a drastic change in the hydrological balance relative to the modern situation, which is a simple antiestuarine flow of surface Atlantic inflow balanced by evaporative loss and deep water return flow through the Gibraltar Straits [Wiist, 1961; Lacombe and Tchernia, 1972]. Oicusson [1961] proposed that the influx of fresh water from the surrounding land and especially from the Black Sea, following its postglacial reconnection with the Mediterranean through the Bosphorus and Dardenelles Straits, led to a decrease in the surface salinity in the eastern basin of the Mediterranean, and this caused a density stratification sufficient to impede or halt bottom water formation. Kullenberg [1952] had earlier argued, by analogy with the stagnant basins of the modem Baltic, that both the supply of oxygen to the bottom waters should be low and the supply of organic matter should be high for organic- and sulphide-rich layers to form in the sediments of the eastern Mediterranean. Thus the lack of replenishment of dissolved oxygen to the deep basin waters due to water column stratification has become the widely accepted model for sapropel formation.

Temperature-corrected oxygen isotope anomalies of planktonic foraminifera have been interpreted as showing that sea surface salinities (SSS) were significantly lower during sapropel formation [Williams et al., 1978], a potential cause of the larger 
range of Mediterranean foraminiferal $\delta^{18} \mathrm{O}$ values than is found in open ocean cores [Vergnaud-Grazzini et al., 1986]. More recent analyses of the isotopic foraminiferal record [Kallel et al., 1997b; Rohling and De Rijk, 1999] support the interpretation of significantly lower SSS during the formation of S1 (Si2). Kallel et al. [1997b] concluded that SSS was more or less uniform throughout the eastern and western basins and that surface density was higher in the west, leading to inflow of deep water from the western basin. In contrast, Rohling and De Rijk [1999] found that an east-west salinity gradient is still consistent with the data, although there appears to have been a marked water $\delta^{18} \mathrm{O}$ depletion in the Levantine Basin most likely due to the influence of high Nile discharge [Rossignol-Strick et al., 1982]. Since water $\delta^{18} \mathrm{O}$ is not a conservative property controlled solely by the precipitation-evaporation balance, Rohling and De Rijk, [1999] were reluctant to provide estimates of the latter for $\mathrm{S} 1$ (Si2) time because the translation of water $\delta^{18} \mathrm{O}$ changes to sea surface salinity changes is not straightforward. Finally, the modeling results of Myers et al. [1998] suggest that the adoption of the inferred S1 (Si2) salinity changes of Thunell and Williams [1989], Kallel et al. [1997a] and Rohling and De Rijk [1999] leads to solutions that have antiestuarine flow, as at the present, throughout the Mediterranean.

Rossignol-Strick [1985] and Rossignol-Strick et al. [1982] correlated the temporal record of sapropels to large increases in freshwater input from the Nile River, which respond directly to monsoonal rainfall over eastern tropical Africa. Rossignol-Strick [1987] also suggested that increased runoff from Eurasian rivers contributed to the change in the hydrological balance in the eastern Mediterranean, and this is supported by the oxygen isotopic composition of Late Pleistocene [Jenkins and Williams, 1984] and Pliocene [Gudjonsson and van der Zwaan, 1985] planktonic foraminifera in the sapropels. Evidence for much more humid conditions in the eastern Mediterranean during S1 (Si2) time also comes from pollen rescrds from North Africa [StreetPerrott and Perrott, 1993] and southam Europe [Wijmstra et al., 1990; Cheddadi et al., 1991; Rossignol-Strick, 1995] as well as records of North African and Levantine lake levels (summarized by $Y u$ and Harrison [1996]). Bar-Matthews et al. [1999] have reviewed existing knowledge on the wetter climate of the Negev Desert during the last $140 \mathrm{kyr}$ based on the isotopic composition of speleothems. These data are in good agreement with the results of climate model simulations of Holocene climates over Africa [Kutzbach and Otto-Bliesner, 1982; Kutzbach and Guetter, 1986]. During the formation of $\mathrm{S} 1$ ( $\mathrm{Si} 2$ ) between 7.3 and $9.3 \mathrm{kyr}$ ago, increased solar radiation at $30^{\circ} \mathrm{N}$, due to the occurrence of perihelion in July and an axial tilt of $24.2^{\circ}$ (compared to the modem value of $23.4^{\circ}$ ), led to a considerable strengthening of the land-ocean pressure gradient. This caused stronger onshore air flow into northern and eastern Africa, which led to increased humidity and a larger effective moisture (precipitation minus evaporation) flux over the land [Kutzbach and Street-Perrott, 1985]. Thus monsoonal rainfall over the Ethiopian Highlands was much greater, leading to greater runoff into the eastern Mediterranean [Rossignol-Strick, 1983]. From older paleolake records this pattern of increasing humidity in the Sahara/Sahel region appears to have been repeated in stages 5,7 , and 9 [Szabo et al., 1995], coincident with the formation of sapropels in core MD 84641 at these times. Sapropel formation in the eastern Mediterranean is also coeval with marked decreases in SSS in the

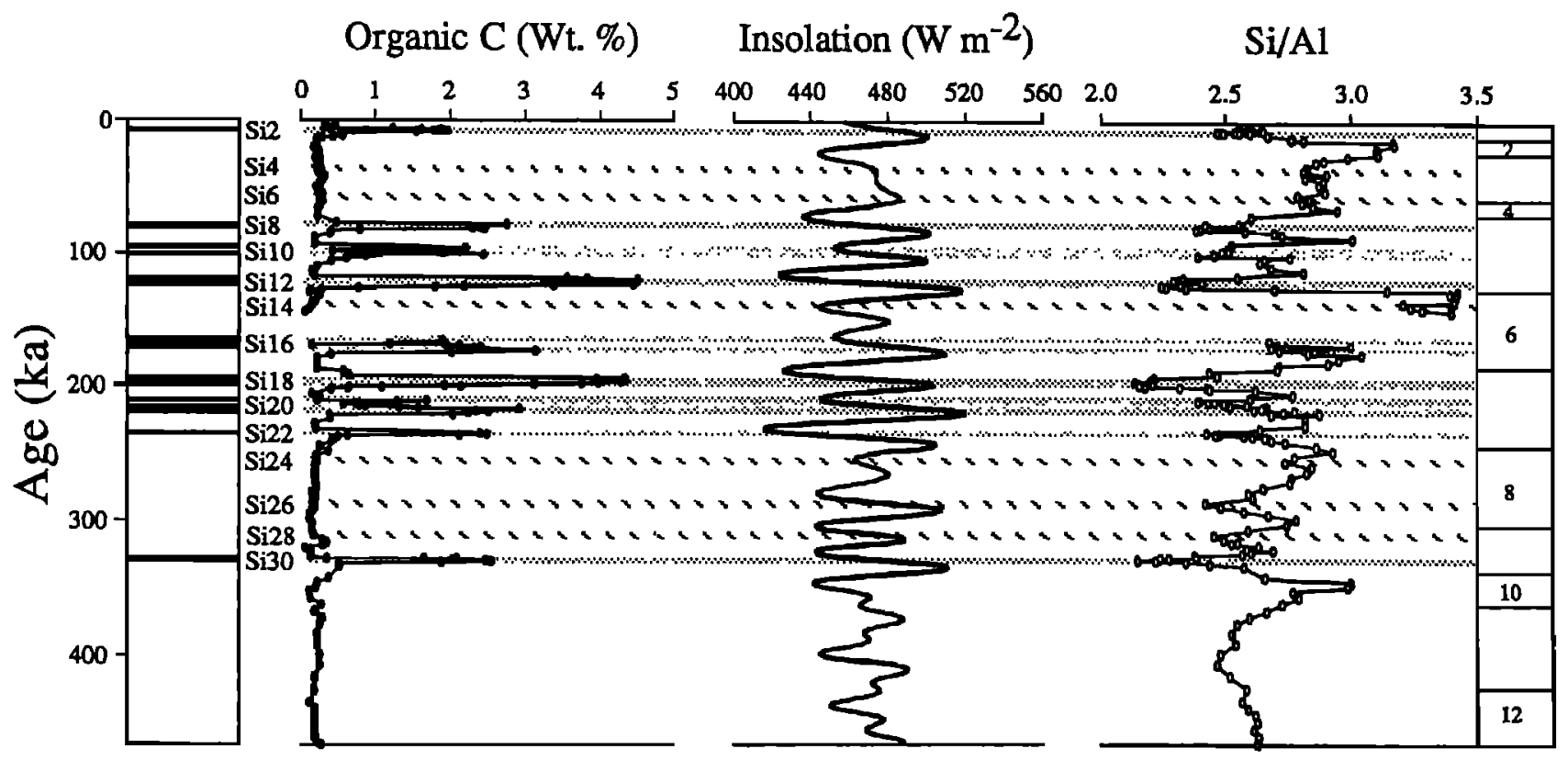

Figure 11. Time scale of sapropel occurrence in core MD 84641 and summer insolation at $65^{\circ} \mathrm{N}$. Insolation data $\left(\mathrm{W} / \mathrm{m}^{2}\right)$ derived from the Laskar90 series [Laskar, 1990] by means of the AnalySeries software [Paillard et al., 1996]. Observable sapropels, as defined by the organic $C$ maxima, are indicated by the stippled pattern, and the positions of the "ghost" and missing sapropels, as defined by mininna in $\mathrm{Si} / \mathrm{Al}$, are indicated by the oblique line pattern. The insolation-based sapropel numbering scheme of Langereis ef al. [1997], even numbers corresponding to insolation maxima, is indicated on the left, and shows that all events that could have led to sapropel formation are present in core MD 84641 . 
Andaman Sea due to increased monsoonally driven runoff from the Indian subcontinent [Kallel et al., 2000], testifying to the enhanced atmospheric transport of moisture from ocean to land.

According to Thunell and Williams [1989], the SSS contrast between sapropel S1 (Si2) and the LGM amounts to 2-3\%o. The inferred higher LGM SSS is consistent with extensive information on the existence of dry and cold open steppe-like conditions over large tracts of North Africa at the LGM [StreetPerrott and Perrott, 1993]. The most recent modeling study [Rohling, 1999] has found that average glacial salinities were probably $41-42 \%$ and, by analogy with the modern situation, somewhat higher in the eastern basin, consistent with the presence of abundance high- $\mathrm{Mg}$ calcite in eastern Mediterranean marls. High-Mg calcite also occurs abundantly in Red Sea sediments [Gevirtz and Friedman, 1966] where current battom water salinities are $\sim 40 \%$ [Locke and Thunell, 1988] owing to high evaporation rates. Although the inferred higher LGM SSS does not necessarily mean that the climate was more arid (because of the complicated relationship between evaporation rate and water exchange), the indication of greater aeolian input (higher quartz/clay, Si/Al, and $\mathrm{Zr} / \mathrm{Al}$ ) during these intervals in core MD 84641 does point to somewhat drier conditions on land or higher wind speeds.

The timing of sapropel formation with respect to the relevant insolation timeseries is shown in Figure 11. Maxima in summer insolation correspond to maxima in the monsoon index [Rossignol-Strick, 1983, 1984], the insolation gradient between the equator and the tropics, which drives more intense monsoonal circulation. Organic carbon peaks in each of the sapropels lag the insolation maxima by 3-9 kyr. Hilgen [1991] found that there was a $4 \mathrm{kyr}$ lag between the sapropels S1 (Si2) to S12 (Si44) and the peaks of the precession index of Berger [1978], whereas Lourens et al. [1996] introduced a $3 \mathrm{kyr}$ lag between the midpoints of sapropels and sumuner insolation maxima of Laskar [1990]. The significant and reproducible lag of sapropel formation evidently reflects a lag in the thermal contrast between the tropics and the equator driven by an offset in summer solstice-perihelion alignment [Short and Mengel, 1986]. These authors also pointed out that the peak thermal contrast $3 \mathrm{kyr}$ after maximum insolation translates into a greater moisture availability in the rainy season, amounting to a $50 \%$ change in saturation vapor pressure, pointing to a significant impact of orbital variations on the tropical hydrological cycle.

Variations in Si/Al in core MD 84641 are coherent with changes in summer insolation at $65^{\circ} \mathrm{N}$ (Figure 11). As discussed previously, minima in the ratio mark the positions of each of the sapropels in this core. However, in addition, there are clear minima in stages 8 and 9, where sapropels are absent, that are lagged by 2-3 kyr with respect to insolation and very small, but significant, minima in stage 3 , where there is a low-amplitude double insolation minimum. Thus the $\mathrm{Si} / \mathrm{Al}$ ratio appears to be well tuned to the insolation curve and provides a secure record of conditions that could have led to the formation of sapropels in the eastern Mediterranean. This provides a more complete record of sapropel-forming conditions than the down core presence/absence of organic-rich sapropels.

\subsection{Glacial Sapropels}

The apparently anomalous occurrence of sapropel S6 (Si16) in glacial stage 6 has been pointed out by Cita et al. [1977] and
Rossignol-Strick [1983]. The $\delta^{18} \mathrm{O}_{\text {ruber data from core MD }}$ 84641 (Figure 2) as well as several other cores from the eastern Mediterranean clearly show that this stage was fully glacial. Moreover, the abundance of $G$. ruber decreases drastically and $G$. bulloides increases at this horizon, consistent with much cooler surface water conditions [Kallel et al., 2000]. As discussed in section 3.7, the trigger for sapropel formation is evidently a drastic change in the hydrological balance of the eastern Mediterranean, driven by precessionally modulated insolation changes. Evidence of such changes during glacial as well as interglacial stages is not difficult to find in view of the timing of the major glacial-interglacial fluctuations and the insolation record over the last $800 \mathrm{kyr}$. Low-latitude $\left(23.5^{\circ}\right)$ summer insolation during stage 6 was as high as that during events 5.1 and 5.3 and only slightly lower than that during events 5.5 and 7.1 [Mélières et al., 1997]. Thus, in spite of a fully glacial climate condition at high latitudes the strong insolation maximum at 175 kyr was sufficient to change the hydrological state of the eastern Mediterranean and induce the formation of a sapropel (S6 or Si16) at $\sim 168 \mathrm{kyr}$. The driving force for such hydrological changes is in the low latitudes (the monsoons and subtropical precipitation patterns), and these are controlled mainly by precessional insolation changes [Rossignol-Strick, 1985]. Possible reasons for the fact that the climate remained in a glacial state in spite of the relatively high insolation maximum at $175 \mathrm{kyr}$ have recently been addressed by Ridgwell et al. [1999].

\subsection{Palaeoproduction During Sapropel Formation}

The geochemical data can be used to estimate plankton production during the sapropel events in the eastern Mediterranean. The sedimentary accumulation rate of excess $\mathrm{Ba}$ (relative to the aluminosilicate background) in $\mathrm{S} 1$ ( $\mathrm{Si2}$ ), using the ${ }^{14} \mathrm{C}$-derived linear sedimentation rate of $\mathrm{S} 1$ (Si2) (data from Fontugne et al. [1994]) and the concentration of biogenous $\mathrm{Ba}$ (the excess relative to a $\mathrm{Ba} / \mathrm{Al}$ ratio of 0.003 ), implies a palaeoproduction of $150 \mathrm{~g} \mathrm{C}^{2} \mathrm{yr}^{-1}$ using the barite-based algorithm of Paytan et al. [1996]. Using the method of Dymond et al. [1992] to derive the water column settling flux of biobarium (which takes account of the aegree of preservation of $\mathrm{Ba}$ in the sediment) and the relationship between biobarium flux and new production (which can be equated with the export flux of organic matter below the photic zone [Eppley and Peterson, 1979]) defined by François et al. [1995] gives an estimate of new production of around $5.3 \mathrm{~g} \mathrm{C} / \mathrm{m}^{2} \mathrm{yr}^{-1}$. These two values suggest that production and organic settling fluxes during $\mathrm{Si}(\mathrm{Si2})$ were roughly an order of magnitude larger than modern values from the central eastern basin, which are of order 10-20 $\mathrm{g} \mathrm{C}^{2} \mathrm{~m}^{2} \mathrm{yr}^{-1}$ and $<1 \mathrm{~g} \mathrm{C} \mathrm{m}^{2} / \mathrm{yr}^{-1}$, respectively [Berman et al., 1984a, 1984b]. It is unlikely that the very low production levels determined today in the eastern basin are not representative of the production conditions prior to the completion of the Aswan High Dam in 1965 because the high nutrient levels and high phytoplankton cell counts off Egypt before 1965 were confined to a relatively narrow strip $<60 \mathrm{~km}$ wide off the river mouth, the offshore region being an "unproductive" zone [Halim et al., 1967].

We have not attempted to reconstruct palaeoproduction levels from the accumulate rate of organic carbon in the sediment [Müller and Suess, 1979; Sarnthein et al., 1987] because the carbon accumulation rate in marine sediments is tightly controlled by the linear sedimentation rate [Middelburg et al., 1997]. The 
calibration of the method for determining palaeoproduction from sedimentary carbon accumulation rates therefore produces results that largely reflect sedimentation rate variations rather than the settling flux of organic matter from the sea surface.

The higher production during sapropel formation that we have deduced from the geochemical evidence is strongly supported by the results of studies of planktonic foraminifera [Rohling, 1989; Lourens et al., 1992], ostracodes [van Harten, 1987], calcareous nanofossils [Castradori, 1993], and diatoms [Schrader and Matherne, 1981; Kemp et al., 1999]. The latter authors speculate that diatom fluxes could well have been high during all sapropel periods in spite of the poor preservation of diatom opal in the sediments because of the low dissolved silicon concentrations in deep Mediterranean waters. The diatom groups preserved (rhizosolenids and Hemiaulis) are typical of stratified waters where high production is maintained toward the base of a deep photic zone. The results of the modeling study of Stratford et al. [2000] suggest that a full circulation reversal of the eastern Mediterranean [Berger, 1976] is required to increase production sufficiently for sapropels to form over the entire basin.

\section{Conclusions}

Mediterranean sapropels are organic-rich, fine-grained muds that formed during periods of greatly altered freshwater balance. The mineralogical and chemical compositions of these deposits are significantly different from the associated marls; they are finer grained, and they contain diagnostic clay mineral phases that point to a southern source or sources. Marls lying immediately below the sapropels are coarser grained and they contain high concentrations of high- $\mathrm{Mg}$ calcite together with clay minerals characteristic of northern and/or western sources. These contrasts suggest that transport agencies (most likely aeolian) for the terrigenous sediment fraction were more vigorous during the accumulation of the marls and that deep water salinities were quite different at times of sapropel and marl deposition. These features can be reconciled if conditions in the eastern Mediterranean were nore arid during marl formation, leading to more evaporative water loss and higher wind speeds. Primary production was higher during sapropel formation, causing a large increase in the settling flux of organic matter to the basin floor. This would have drawn down deep water oxygen levels, which also might have been replenished less frequently if circulation restricted deep water renewal: The sediments themselves were anoxic during sapropel formation, although the upper sections of composite sapropels show clear evidence of oxygenated bottom waters even though production was high. The positions of missing and ghost sapropels can be identified from the down core distributions of lithogenous tracers (quartz/clay, Si/Al, and $\mathrm{Zr} / \mathrm{Al}$ ratios) that are not affected by postdepositional diagenetic modification of the sedimentary record. The reconstructed record shows that the conditions for potential sapropel formation occurred slightly after every significant insolation maximum during the last $350 \mathrm{kyr}$.

Acknowledgments. This study would not have been possible without the extensive laboratory assistance of Shirley French, Mark Noyon, and especially Maureen Soon (UBC). We are grateful to Markus Kienast, Tom Pedersen, and John Thomson for informal reviews of the manuscript, and Gert de Lange, Eelco Rohling, and Rolf Wehausen for very helpful and collegial formal journal reviews. The collection of core MD 84641 was made possible by Territoire des Terres Australes et Antarctiques Françaises (Nö̈ Cruise of the R/V Marion-Dufresne). S.E.C. acknowledges support from CNRS-CEA (France), the Natural Sciences and Engineering Research Council (Canada), and the Canada Council during the completion of this study. LSCE contribution 495 . The data presented here are available from the senior author at calvert@eos.ubc.ca.

\section{References}

Aksu, A.E., D. Yasar, and P.J. Mudie, Origin of late glacial-Holocene hemipelagic sediments in the Aegean Sea: Clay mineralogy and carbonate cementation, Mar. Geol., 123, 33-59, 1995.

Bard, E., M. Ámold, B. Hamelin, N. TisneratLaborde, and G. Cabioch, Radiocarbon calibration by means of mass spectrometric ${ }^{230} \mathrm{Th} / 234 \mathrm{U}$ and ${ }^{14} \mathrm{C}$ ages of corals: an updated database including samples from Barbados, Mururoa and Tahiti, Radiocarbon, 40 (3), 1085-1092, 1998.

Bar-Matthews, M., A. Ayalon, A. Kaufman, and G.J. Wasserburg, The eastern Mediterranean paleoclimate as a reflection of regional events: Soreq cave, Israel, Earth Planet. Sci. Lett., 166. 85-95, 1999.

Berger, A.L., Long-term variations of caloric insolation resulting from the Earth's orbital elements, Quaternary Res., 9, 139-167, 1978.

Berger, W.H., Biogenous deep sea sediments: Production, preservation and interpretation, in Treatise on Chemical Oceanography, edited by J. P. Riley and R. Chester, pp. 265-388, Academic, San Diego, Calif., 1976

Berman, T., Y. Azov, and D. Townsend, Understanding oligotrophic oceans: Can the eastern Mediterranean be a useful model? in Marine Plankton and Productivin, edited by $O$. Holm-Hansen, $L$. Bolis and R. Gilles, pp. 99-112, Springer-Verlag, New York, 1984a.
Berman, T., D. Townsend, S.Z. El Sayed, C.C. Trees, and Y. Azov, Optical transparency, chlorophyll and primary productivity in the eastem Mediterranean near the Israeli coast, Oceanol. Acta, 7 (3), 367-372, 1984b.

Bradley, W.H., Mediterranean sediments and Pleistocene sea levels, Science, 88, 376-379, 1938.

Brolsma, M.J., Quantitative foraminiferal analysis and environmental interpretation of the Pliocene and topmost Miocene on the south coast of Sicily, Utrecht Micropaleontol. Bull., 18, 1-159, 1978.

Brooks, C.E.P., Climate Through the Ages, 395 pp., Dover, Mineola, N.Y., 1949.

Calvert, S.E., The mineralogy and geochemistry of near-shore sediments, in Chemical Oceanography, edited by J. P. Riley and R. Chester, pp. 187-280, Academic Press, San Diego, Calif., 1976.

Calvert, S.E., Geochemistry of Pleistocene sapropels and associated sediments from the eastern Mediterranean, Oceanol. Acta, 6, 255-267, 1983.

Calvert, S.E., Geochemistry and origin of the Holocene sapropel in the Black Sea, in Facets of Modern Biogeochemistry, edited by V. Ittekkot et al., pp. 326-352, SpringerVerlag, New York, 1990.

Calvert, S.E., and T.F. Pedersen, Geochemistry of Recent oxic and anoxic marine sediments: Implications for the geological record, Mar. Geol., 113, 67-88, 1993.

Calvert, S.E., B. Nielsen, and M.R. Fontugne,
Evidence from nitrogen isotope ratios for enhanced productivity during formation of eastern Mediterranean sapropels, Nature. 359, 223-225, 1992.

Castradori, D., Calcareous nannofossils and the origin of eastern Mediterranean sapropels, Paleoceanography, 8, 459-471, 1993.

Chamley, H., Sur la sedimentation argileuse profond en Mediterranee, in The Mediterranean Sea, edited by D. J. Stanley, pp. 387-399, Van Nostrand Reinhold, New York 1972 .

Cheddadi, R., M. Rossignol-Strick, and M.R. Fontugne, Eastern Mediterranean palaeoclimates from 26 to $5 \mathrm{ka}$ B.P. documented by pollen and isotopic analysis of a core from the anoxic Bannock Basin, Mar. Geol., 100, 53-66, 1991.

Church, T.M., Marine barite, Ph.D. dissertation thesis, Univ. Calif. at San Diego, 1970.

Cita, M.B., and D. Grignani, Nature and origin of Late Neogene Mediterranean sapropels, in The Nature and Origin of Cretaceous Carbon-rich Facies, edited by $S$. $O$. Schlanger and M. B. Cita, pp. 165-196, Academic Press, San Diego, Calif., 1982.

Cita, M.B., C. Vergnaud-Grazzini, C. Robert, H. Chamley, N. Ciaranfi, and S. Donofrio, Paleoclimatic record of a long deep-sea core from the eastem Mediterranean, Quat. Res., $8,205-235,1977$.

Cramp, A., and G. O'Sullivan, Neogene sapropels in the Mediterranean: A review, Mar. Geol., 153, 11-28, 1999. 
de Lange, G.J., J.J. Middleburg, and P.A. Pruysers, Middle and late Quaternary depositional sequences and cycles in the eastern Mediterranean, Sedimentology, 36 , $151-158,1989$.

De Rijk, S., A. Hayes, and E.J. Rohling, Eastern Mediterranean sapropel Si interruption: an expression of the onset of climatic detereoration around $7 \mathrm{ka} \mathrm{BP}$, Mar. Geol., 153, 337-343, 1999.

Dominik, J., and P. Stoffers, The influence of late Quaternary stagnations on clay sedimentation in the eastern Mediterranean Sea, Geol Rundsch, 68, 302-317, 1978.

Dymond, J., E. Suess, and M. Lyle, Barium in deep-sea sediment: A geochemical proxy for paleoproductivity, Paleoceanography, 7 (2), 163-181, 1992.

Emeis, K.C., and S.S. Party, Paleoceanography and sapropel introduction, in Proc. Ocean Drill. Program Initial Rep., 160, pp. 21-26, 1996.

Eppley, R.W., and B.J. Peterson, Particulate organic matter flux and planiktonic new production in the deep ocean, Nature, 282 , $677-680,1979$.

Fischer, A.G., and R.E. Garrison, Carbonate lithification on the sea floor, J. Geol., 75, 488-496, 1967

Fontugne, M.R., and S.E. Calvert, Late Pleistocene variability of the carbon isotopic composition of organic matter in the eastem Mediterranean: Monitor of changes in carbon sources and atmospheric $\mathrm{CO}_{2}$ concentrations, Paleoceanography, 7, 1-20, 1992.

Fontugne, M., M. Arnold, L. Labeyrie, S.E. Calvert, M. Paterne, and J.C. Duplessy, Palaeoenvironment, sapropel chronology and Nile river discharge during the last 20,000 years as indicated by deeep sea sediment records in teh Eastern Mediterranean, in Late Quaternary Chronology and Paleoclimates of Eastern Mediterranean., edited by $O$. Bar Yosef and R. Kra, pp. 75-88, Radiocarbon, Tucson, 1994

Foucault, A., and F. Mélières, Palaeoclimatic cyclicity in central Mediterranean Pliocene sediments: The mineralogical signal, Palaeogeogr. Palaeoclimatol. Palaeoecol., 158, 311-323, 2000.

François, R., S. Honjo, S.J. Manganini, and G.E. Ravizza, Biogenic barium fluxes to the deep sea: Implications for paleoproductivity reconstruction, Global Biogeochem. Cycles, 9, 289-303, 1995.

Ganor, E., and Y. Mamane, Transport of Saharan dust across the eastern Mediterranean, Atmos. Environ., 16, 581$587,1982$.

Gevirtz, J.L., and G.M. Friedman, Deep-sea carbonate sediments of the Red Sea and their implications on marine lithification, $J$. Sediment. Petrol., 36, 143-151, 1966.

Gingele, F., and A. Dahmke, Discrete barite particles and barium as tracers of palaeoproductivity in South Atlantic sediments, Paleoceanography, 9, 151-168, 1994.

Goldsmith, J.R., and D L. Graf, Relation between lattice constants and composition of the Ca-Mg carbonates, Am. Mineral., 43, 84-101, 1958.

Gudjonsson, L., and G.J. van der Zwaan, Anoxic events in the Pliocene Mediterranean: stable isotope evidence of run-off, Proc. K. Ned. Akad. Wet., 88, 69 $82,1985$.

Halim, Y., S.K. Guergues, and H.H. Saleh, Hydrographic conditions and plankton in the south east Mediterranean during the last normal Nile flood (1964), Int. Rev. Gesamten. Hydrobiol., 52, 401-425, 1967.

Higgs, N.C., J. Thomson, T.R.S. Wilson, and I.W. Croudace, Modification and complete removal of eastem Mediterranean sapropels by postdepositional oxidation, Geology, 22 , 423-426, 1994

Hilgen, F.J., Sedimentary rhythms and highresolution chronostratigraphic correlations in the Mediterranean Pliocene, Newsl. Stratigr. 17, 109-127, 1987.

Hilgen, F.J., Sedimentary cycles and an astronomically controlled, oscillatory system of climatic change during the late Cenozoic in the Mediterranean, Paleobiol Continentale, 17, 25-33, 1990.

Hilgen, F.J., Astronomical calibration of Gauss to Matuyama saprorels in the Mediterranean and implication for the geomagnetic polarity time scale, Earth Planet. Sci. Lett., 104, 226-244, 1991

Hilgen, F.G., W. Krijgsman, C.G Langereis L.J. Lourens, A. Santarelli, and W.J. Zachariasse, Extending the astronomical (polarity) time scale into the Miocene, Earth Planet. Sci. Lett., 136, 495-510, 1995.

Imbrie, J., J.D. Hays, D.G. Martinson, A McIntyre, A.C. Mix, J.J. Morley, N.G. Pisias, W.L. Prell, and N.J. Shackleton, The orbital theory of Pleistocene climate: Support frgm a revised chronology of the marine $\delta^{18} \mathrm{O}$ record, in Milankovitch and Climate, Vol. 1, edited by A. L. Berger et al., pp. 269-305, D. Reidel, Norwell, Mass., 1984.

Jenkins, J.A., and D.F. Williams, Nile water as a cause of eastern Mediterranean sapropel formation: Evidence for and against, $\mathrm{Mar}$ Micropaleontol., 9, 521-534, 1984.

Jonkers, H.A., Pliocene benthonic foraminifera from homogeneous and laminated marls on Crete: I.G.C.P. Project no. 1, Utrecht Micropaleontol. Bull., 31, 1-179, 1984.

Jorissen, F.J., Benthic foraminiferal successions across late Quaternary Mediterranean sapropels, Mar. Geol., 153, 91-101, 1999

Kallel, N., M. Paterne, J.-C. Duplessy, C. Vergaud-Grazzini, C. Pujol, L. Labeyrie, M Arnold, M. Fontugne, and C. Pierre, Enhanced rainfall in the Mediterranean region during the last sapropel event, Oceanol. Acta, 20, 697-712, 1997a.

Kallel, N., M. Paterne, L. Labeyrie, J.-C. Duplessy, and M. Amold, Temperature and salinity records of the Tyrrhenian Sea during the last 18,000 years, Palaeogeogr. Palaeoclimatol. Palaeoecol., 135, 97-108, $1997 \mathrm{~b}$.

Kallel, N., J.C. Duplessy, L. Labeyrie, M Fontugne, M. Paterne, and M. Montacer Mediterranean pluvial periods and saprope formation during the last 200,000 years, Palaeogeogr. Palaeoclimatol. Palaeoecol. $157,45-58,2000$.

Kemp, A.E.S., and J.G. Baldauf, Vast Neogene laminated diatom mat deposits from the eastern equatorial Pacific Ocean, Nature, 362, 141-144, 1993.

Kemp, A.E.S., R.B. Pearce, I. Koizumi, J. Pike, and S.J. Rance, The role of mat-forming diatoms in the formation of Mediterranean sapropels, Nature, 398, 57-61, 1999.

Krom, M.D. R.A. Cliff, L.M. Eijsink, B. Herut, and $R$. Chester, The characterisation of Saharan dusts and Nile particulate matter in sediments from the Levantine basin using Sr isotopes, Mar. Geol., 155, 319-330, 1999 a.

Krom, M.D., A. Michard, R.A. Cliff, and K. Strohle, Sources of sediment to the Ionian Sea and western Levantine basin of the eastern Mediterranean during S-1 sapropel times, Mar. Geol., 160, 45-61, 1999b.

Kullenberg, B., On the salinity of the water contained in marine sediments, Goteborgs Kungl. Vetenskaps. Vitt-Samhal. Handlingar, 6B, 3-37, 1952.

Kutzbach, J.E., and P.J. Guetter, The influence of changing orbital parameters and surface boundary conditions on climate simulations for the past 18,000 years, $J$. Atmos. Sci., 43, 1726-1759, 1986.

Kutzbach, J.E., and B.L. Otto-Bliesner, The sensitivity of the African-Asian monsoonal climate to orbital parameter changes for 9000 years B.P. in a low-resolution General Circulation Model, J. Atmos. Sci., 39, 1177 1188,1982

Kutzbach, J.E., and F.A. Street-Perrott, Milankovitch forcing of fluctuations in the level of tropical lakes from 18 to $0 \mathrm{kyr} B P$, Nature, 3I7, 130-134, 1985.

Lacombe, H., and P. Tchernia, Caractères hydrologiques et circulation des eaux en Mediterranée, in The Mediterranean Sea, edited by D. J. Stanley, pp. 25-36, Van Nostrand Reinhold, New York, 1972.

Langereis, C.G., M.J. Dekkers, G.J. de Lange, M. Paterne, and P.J.M. van Santvoort Magnetostratigraphy and astronomical calibration of the last $1.1 \mathrm{Myr}$ from an eastern Mediterranean piston core and dating of short events in the Brunhes, Geophys. J. Int., 129, 75-94, 1997.

Laskar, J., The chaotic motion of the solar system: A numerical estimation of the size of the chaotic zones, Icarus, 88, 266-291, 1990

Locke, S., and R.C. Thunell, Paleoceanographic record of the last glacial/ interglacial cycle in the Red Sea and Gulf of Aden, Palaeogeogr. Palaeoclimatol. Palaeoecol., 64, 163-187, 1988.

Lourens, L.J., F.J. Hilgen, L. Gudjonsson, and W.J. Zachariasse, Late Pliocene to early Pleistocene astronomically forced sea surface productivity and temperature variations in the Mediterranean, Mar. Micropaleontol., 19, 49-78, 1992.

Lourens, L.J., A. Antonarakou, F.J. Hilgen, A.A.M. Van Hoof, C. Vergnaud-Grazzini, and W.J. Zachariasse, Evaluation of the Plio-Pleistocene astronomical timescale Paleoceanography, 11, 391-413, 1996.

Lynn, D.C., and E. Bonatti, Mobility of manganese in diagenesis of deep-sea sediments, Mar. Geol., 3, 457-474, 1965.

Mahowald, N., K. Kohfeld, M. Hansson, Y. Balkanski, S.P. Harriosn, I.C. Prentice, M Schulz, and H. Rodhe, Dust sources and deposition during the last glacial maximum and current climate: A comparison of model results with paleodata from ice cores and marine sediments, J. Geophys. Res., 104 (D13), 15,895-15,916, 1999.

Martinson, D.G., N.G. Pisias, J.D. Hays, J. Imbrie, T.C. Moore, and N.J. Shackleton, Age dating and the orbital theory of the ice ages: development of a high-resolution 0 to 300,000-year chronostratigraphy, Quat. Res., 27, 1-29, 1987

Mélières, M.-A., M. Rossignol-Strick, and B. Malaizé, Relation between low latitude insolation and $\delta^{18} \mathrm{O}$ change of atmospheric oxygen for the last $200 \mathrm{kyrs}$, as revealed by Mediterranean sapropels, Geophys. Res. Lett., 24 (10), 1235-1238, 1997.

Middelburg, J.J., K. Soetaert, and P.M.J. Herman. Empirical relationships for use in global diagenetic models, Deep Sea Res., Part I, 44, 327-344, 1997.

Milliman, J.D., and J. Müller, Precipitation and lithification of magnesian calcite in the 
deep-sea sediments of the eastern Mediterranean Sea, Sedimentology, 20, 29. $45,1973$.

Milliman, J.D., D.A. Ross, and T.-L. Ku, Precipitation and lithification of deep-sea carbonates in the Red Sea, J. Sediment. Petrol., 39, 724-736, 1969

Müller, J., and F. Fabricius, Magnesian-calcite nodules in the Ionian deep sea: an actualistic model for the formation of some nodular limestones, in Pelagic Sediments: On Land and Under the Sea, edited by K. J. Hsu and H. C. Jenkyns, 1, 235-247, Spec. Publ. Int. Assoc. Sedimentol. 1974.

Muiller, P.J., and E. Suess, Productivity, sedimentation rate, and sedimentary organic matter in the oceans, I, Organic carbon preservation., Deep Sea Res., 26A, 1347 $1362,1979$.

Murat, A., Pliocene-Pleistocene occurrence of sapropels in the western Mediterranean Sea and their relation to eastern Mediterranean sapropels, in Proc. Ocean Drill. Program Sci. Results, 161, edited by R. Zahn, M. C. Comas and A. Klaus, pp. 519-528, 1999.

Myers, P.G., K. Haines, and E.J. Rohling, Modeling the paleocirculation of the Mediterranean: The Last Glacial Maximum and the Holocene with emphasis on the formation of sapropel $S 1$ Paleoceanography, 13, 586-606, 1998.

Oggioni, E., and L. Zandini, Response of benthic foraminifera to stagnant episodes; a quantitative study of core BAN $81-23$. eastern Mediterranean., in Exta.tt and ancient anoxic basin conditions in the eastern Mediterranean., edited by J. E. van Hinte, M. B. Cita and C. H. van der Weijden, pp. 241-261, Free Univ. Mar. Geol. Cen., Amsterdam, 1987.

Olausson, E., Studies of deep-sea cores, Rep. Swed. Deep Sea Exped., 8, 337-391, 1961.

Paillard, D., L.D. Labeyrie, and P. Yiou, Macintosh program performs time-series analysis, Trans. AGU, 77 (39), 379, 1996.

Passier, H.F., J.J. Middelburg, G.J. de Lange, and M.E. Bottcher, Modes of sapropel formation in the eastern Mediterranean: Some constraints based on pyrite contents, Mar. Geol., 153, 199-219, 1999.

Paytan, A., M. Kastner, E.E. Martin, J.D Macdougall, and T. Herbert, Marine barite as a monitor of seawater strontium isotope composition, Nature, 366, 445-449, 1993.

Paytan, A., M. Kastner, and F.P. Chavez, Glacial to interglacial fluctuations in productivity in the equatorial Pacific as indicated by marine barite, Science, 274 , 1355-1357, 1996

Petit, J.-R., lce age aerosol content from east Antarctic ice core samples and past wind strength, Nature, 293, 391-394, 1981.

Pruysers, P.A., G.J. De Lange, J.J. Middelburg, and D.J. Hydes, The diagenetic formation of metal-rich layers in sapropel-containing sediments in the eastern Mediterranean, Geochim. Cosmochim. Acta, 57, 527-536, 1993.

Ridgwell, A.J., A.J. Watson, and M.E. Raymo, Is the spectral signature of the $100 \mathrm{kyr}$ glacial cycle consistent with a Milankovitch origin?, Paleoceanography, I4, 437-440, 1999.

Rohling, E.J., Late Quaternary changes in Mediterranean Intermediate Water density and formation rate, Paleoceanography, 4, 531-545, 1989

Rohling, E.L., Review and new aspects concerning the formation of eastern Mediterranean sapropels, Mar. Geol., 122, $1-28,1994$

Rohling, E.J., Environmental control on
Mediterranean salinity and $\delta^{18} \mathrm{O}$, Paleoceanography, 14, 706-7 15, 1999.

Rohling, E.J., and S. De Rijk, Holocene climate optimum and Last Glacial Maximum in the Mediterranean: The marine oxygen isotope record, Mar. Geol., 153, 57-75, 1999.

Rohling, E.J., and F.J. Hilgen, The eastern Mediterranean climate at times of sapropel formation: A review, Geol. Mijnbouw, 70, 253-264, 1991

Rohling, E.J., F.J. Jorissen, and H.C. De Stigter, 200 year interruption of Holocene sapropel formation in the Adriatic Sea, $J$. Micropalaeontol. , 16, 97-108, 1997.

Rossignol-Strick, M., African monsoons, an immediate climate response to orbital insolation, Nature, 304, 46-49, 1983.

Rossignol-Strick, M., Immediate climate response to orbital insolation: Mediterranean sapropels and African monsoon, in Milankovitch and Climate, vol. 1, edited by A. L. Berger et al., pp. 367-368, D. Reidel, Norwell, Mass., 1984

Rossignol-Strick, M., Mediterranean Quaternary sapropels, an immediate response of the African Monsoon to variation of insolation, Palaeogeogr., Palaeoclimatol., Palaeoecol., 49, 237-263, 1985.

Rossignol-Strick, M., Rainy periods and bottom water stagnation initiating brine accumulation and metal concentrations: 1 . The late Quaternary., Paleoceanography, 2, 333-360, 1987.

Rossignol-Strick, M., Sea-land correlation of pollen records in the eastern Mediterranean for the glacial-interglacial transition: Biostratigraphy versus radiometric timescale, Quat. Sci. Rev., 14, 893-915, 1995.

Rossignol-Strick, M., W. Nesteroff, P. Olive, and $C$. Vergnaud-Grazzini, After the deluge: Mediterranean stagnation and sapropel formation, Nature, 295, 105-110, 1982.

Ryan, W.B.F., Stratigraphy of late Quaternary sediments in the eastern Mediterranean, in The Mediterranean Sea, edited by D.J. Stanley, pp. 149-169, Van Nostrand Reinhold, New York, 1972.

Sancetta, C., Mediterranean sapropels: Seasonal stratification yields high production and carbon flux, Paleoceanography, 9, 195-196, 1994.

Sancetta, C., The mystery of the sapropels, Nature, 398, 27-28, 1999.

Sarnthein, M., K. Winn, and R. Zahn, Paleoproductivity of oceanic upwelling and the effect on atmospheric $\mathrm{CO}$, and climatic change during deglaciation tiries, in $A b r u p t$ Climatic Change, edited by W. H. Berger and L. D. Labeyrie, pp. 311-337, D. Reidel, Norwell, Mass., 1987

Schenau, S.J., A. Antonarakou, F.J. Higne, L.J. Lourens, I.A. Nijenhuis, C.H. van der Weijden, and W.J. Zachariasse, Organicrich layers in the Metochia section (Gavdos, Greece): Evidence for a single mechanism of sapropel formation during the past 10 My, Mar. Geol., 153, 117-135, 1999.

Schmitz, B., Barium, equatorial high productivity, and the northward wandering of the Indian continent, Paleoceanography, 2, 197-215, 1987

Schrader, H., and A. Matherne, Sapropel formation in the eastern Mediterranean: evidence from preserved opal assemblages, Micropaleontol., 27 (2), 191-203, 1981.

Short, D.A., and J.G. Mengel, Tropical climatic phase lags and Earth's precession cycle, Nature, 323, 48-50, 1986

Singer, A., Pedogenic palygorskite in the arid environment, in Palygorskite-Sepiolite: Occurrences, Genesis and Uses, edited by
A. Singer and E. Galan, pp. 169-176, Elsevier Sci., New York, 1985.

Stanley, D.J., and A.N. Liyanage, Clay-mineral variations in the northeastern Nile Delta, as influenced by depositional processes, Mar. Geol., 73, 263-283, 1986.

Stanley, D.J., and A. Maldonado, Nile Cone: Late Quaternary stratigraphy and sediment dispersal, Nature, 266, 129-135, 1977.

Stratford, K., R.G. Williams, and P.G. Myers, Impact of the circulation on sapropel formation in the eastern Mediterranean, Global Biogeochem. Cycles, 14, 683-695, 2000.

Street-Perrott, F A and R.A. Perrott, Holocene vegetation, lake levels and climate of Africa, in Global Climates Since the Last Glacial Maximum, edited by H. E. Wright et al, pp. 318-356, Univ. Minn. Press, Minneapolis, 1993.

Szabo, B.J., C.V. Haynes, and T.A. Maxwell, Ages of Quaternary pluvial episodes determined by uranium-series and radiocarbon dating of lacustrine deposits of Eastern Sahara, Palaeogeogr. Palaeoclimatol. Palaeoecol., 113, 227-242, 1995.

Taylor, S.R., and S.M. McLennan, The Continental Crust: Its Composition and Evolution, 312 pp., Blackwell Sci., Oxford 1985.

ten Haven, H.L., M. Baas, J.W. de Leeuw, and P.A. Schenck, Late Quaternary Mediterranean sapropels, I, On the origin of organic matter in sapropel S7, Mar. Geol., $75,137-156,1987 \mathrm{a}$.

ten Haven, H.L M. Baas, J.W. de Leeuw, P.A. Schenck, and H. Brinkhuis, Late Quarernary Mediterranean sapropels, II, Organic geochemistry and palynology of $S$. sapropels and associated sediments, Chem. Geol., 64, 149-167, $1987 \mathrm{~b}$.

ten Haven, H.L., M. Baas, M. Kroot, J.W. deLeeuw, P.A. Schenck, and J. Ebbing, Late Quaternary Mediterranean sapropels, III, Assessment of source of input and palaeotemperature as derived from biological markers, Geochim. Cosmochim. Acta, 51, 803-810, 1987c.

Thompson, G., and V.T. Bowen, Analyses of coccolith ooze from the deep tropical Atlantic, J. Mar. Res., 27, 32-37, 1969.

Thomson, J., N.C. Higgs, I.W. Croudace, S. Colley, and D.J. Hydes, Redox zonation of elements at an oxic/post-oxic boundary in deep-sea sediments, Geochim. Cosmochim. Acta, 57, 579-595, 1993.

Thomson, J., N.C. Higgs, T.R.S. Wilson, I.W Croudace, G.J. de Lange, and P.J.M Santvoort, Redistribution and geochemical behaviour of redox-sensitive elements around $S 1$, the most recent eastern Mediterranean sapropel, Geochim. Cosmochim. Acta, 59, 3487-3501, 1995.

Thomson, J., D. Mercone, G.J. de Lange, and P.J.M. van Santvoort, Review of recent advances in the interpretation of eastern Mediterranean sapropel S1 from geochemical evidence, Mar. Geol., 153, 77 . $89,1999$.

Thunell, R.C., and D.F. Williams, GlacialHolocene salinity changes in the Mediterranean Sea: Hydrographic and depositional effects, Nature, 338, 493-496, 1989.

Tomadin, L., Provenance and dispersal of clay minerals in recent sediments of the central Mediterranean Sea, in Sedimentary Basins of Mediterranean Margins, edited by F. C Wezel, pp. 313-324, Cons. Naz. delle Ric., Bologna, Italy, 1981

Tomadin, L., and V. Landuzzi, Origin and 
differentiation of clay minerals in pelagic sediments and sapropels of the Bannock Basin (eastern Mediterranean), Mar. Geol., $100,35-43,1991$.

Tomadin, L., R. Lenaz, V. Landuzzi, A. Mazzucotelli, and R. Vannucci, Wind blown dusts over the Central Mediterranean Oceanol. Acta, 7, 13-23, 1984.

Troelstra, S.R., G.M. Ganssen, K. Van Der Borg, and A.F.M. De Jong, A late Quaternary stratigraphic framework for the eastern Mediterranean sapropel S1 based on AMS ${ }^{14} \mathrm{C}$ fates and stable oxygen isotopes, Radiocarbon, 33, 15-21, 1991.

Tucholka, P., M.R. Fontugne, F. Guichard, and M. Paterne, The Blake magnetic polarity episode in cores from the Mediterranean Sea, Earth Planet. Sci. Lett., 80, 320-326, 1987.

Turekian, K.K., The marine geochemistry of strontium, Geochim. Cosmochim. Acta, 28 , 1479-1496, 1964

van Harten, D., Ostracodes and the early Holocene anoxic event in the eastern Mediterranean; evidence and implications. Mar. Geol, 75, 263-269, 1987.

van Os, B.J.H., J.J. Middelburg, and G.J. de Lange, Possible diagentic mobilization of barium in sapropelic sediment from the eastern Mediterranean, Mar. Geol., 100, 125-136, 1991.

Van Santvoort, P.J.M., G.J. De Lange, J. Thomson, H. Cussen, T.R.S. Wilson, M.D Krom, and K. Strohle, Active postdepositional oxidation of the most recent sapropel (S1) in sediments of the eastern Mediterranean Sea, Geochim. Cosmochim. Acta, 60, 4007-4024, 1996.
Venkatarathnam, K., and W.B.F. Ryan, Dispersal patterns of clay minerals in the sediments of the eastern Mediterranean Sea Mar. Geol, 11, 261-282, 1971.

Venkatarathnam, K., P.E. Biscaye, and W.B.F. Ryan, Origin and dispersal of Holocene sediments in the eastern Mediterranean Sea in The Mediterranean Sea, edited by D. J Stanley, pp. 455-463, Van Nostrand Reinhold, New York, 1972.

Vergnaud-Grazzini, C., M. Devaux, and $J$. Znaidi, Stable isotope "anomalies" in Mediterranean Pleistocene records, Mar Micropaleontol., 10, 35-69, 1986.

Vergnaud-Grazzini, C., W.B.F. Ryan, and M.B Cita, Stable isotope fractionation, climate change and episodic stagnation in the eastern Mediterranean during the Late Quatemary, Mar. Micropaleontol., 2, 353370, 1977.

Vismara Schilling, A., and W.T. Coulbourn, Benthic foraminiferal thanatofacies associated with Late Pleistocene to Holocene anoxic events in the eastern Mediterranean Sea, J. Foraminiferal Res. 21 (2), 103-125, 1991.

Wehausen, R., and H.-J. Brumsack, Cyclic variations in the chemical composition of eastem Mediterranean Pliocene sediments: A key for understanding sapropel formation. Mar. Geol., 153, 161-176, 1999.

Wijmstra, T.A., R. Young, and H.J.L. Witte An evolution of the climatic conditions during the late Quaternary in northern Greece by means of multivariate analysis of palynological data and comparison with recent phytosociological and climatic data Geol. Mijnbouw, 69, 243-251, 1990.
Williams, D.F, and R.C. Thunell, Faunal and oxygen isotopic evidence for surface water salinity changes during sapropel formation in the eastern Mediterranean, Sediment. Geol, 23, 81-93, 1979.

Willams, D.F., R.C. Thunell, and J.P. Kennett, Periodic freshwater flooding and stagnation of the eastem Mediterranean Sea during the late Quaternary, Science, 201, 252-254 1978 .

Wilson, T.R.S., J. Thomson, S. Colley, D.J. Hydes, N.C. Higgs, and J. Sorensen, Early organic diagenesis: the significance of progressive subsurface oxidation fronts in pelagic sediments, Geochim. Cosmochim. Acta, 49, 811-822, 1985

Wüst, G., On the vertical circulation of the Mediterranean Sea, J. Geophys Res., 66, 3261-3271, 1961.

Yu, G., and S.P. Harrison, An evaluation of the simulated water balance of Eurasia and northem Europe at 6000 y BP using lake status data, Clim. Dyn., 12, 723-735, 1996.

S.E. Calvert, Department of Earth and Ocean Sciences, University of British Columbia, Vancouver, British Columbia, Canada V6T 1Z4. (calvert @eos.ubc.ca)

M.R. Fontugne, Laboratoire des Sciences du Climat et de l'Environnement, UMR CEA/CNRS 1572, Domaine du CNRS, F91198- Gif-sur-Yvette Cedex, France.

(Received December 4, 1999;

revised August 6, 2000;

accepted August 14,2000 .) 